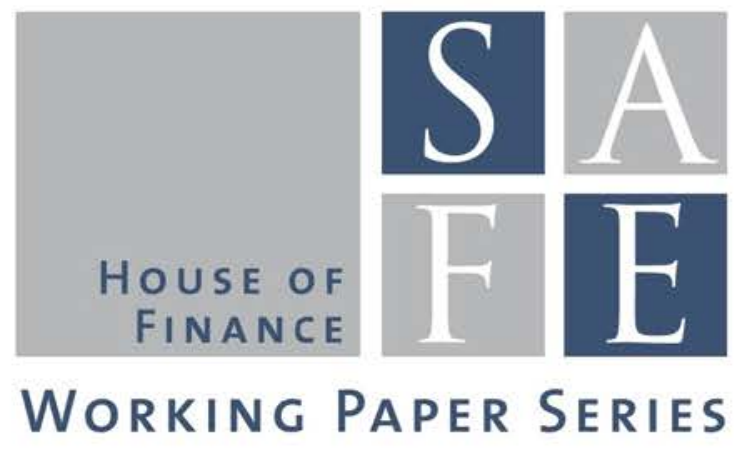

Calebe de Roure - Loriana Pelizzon - Anjan Thakor

\title{
P2P Lenders versus Banks: Cream Skimming or Bottom Fishing?
}

SAFE Working Paper No. 206

SAFE I Sustainable Architecture for Finance in Europe A cooperation of the Center for Financial Studies and Goethe University Frankfurt 


\title{
P2P Lenders versus Banks: Cream Skimming or Bottom Fishing?*
}

\author{
Calebe de Roure \\ Reserve Bank of Australia \\ Loriana Pelizzon \\ SAFE-Goethe University Frankfurt and Ca’ Foscari University of Venice
}

\author{
Anjan Thakor \\ Olin Business School, Washington University \\ FIRST VERSION: January 31, 2017 \\ THIS VERSION: April 18, 2018
}

\begin{abstract}
We develop a simple theoretical model to motivate testable hypotheses about how P2Pplatforms compete with banks for loans. The model predicts that (i) P2P lending grows when some banks are faced with exogenously higher regulatory costs; (ii) P2P loans are riskier than bank loans; and (iii) the risk-adjusted interest rates on P2P loans are lower than those on bank loans. We confront these predictions with data on P2P lending and the consumer bank credit market in Germany and find empirical support. Overall, our analysis indicates the P2P-lenders are bottom fishing when regulatory shocks create a competitive disadvantage for some banks.
\end{abstract}

Keywords: P2P lending, bank lending, competition

JEL Classification: G21

\footnotetext{
*Authors' contact: Calebe de Roure: derourec@rba.gov.au; Loriana Pelizzon: pelizzon@safe.uni-frankfurt.de; and Anjan Thakor: thakor@wustl.edu. The opinions expressed do not necessarily reflect those of the Reserve Bank of Australia. We thank participants at the "New Frontiers in Banking Research: from Corporate Governance to Risk Management" Conference (Rome), RFS FinTech Conference (New York), 2017 Meeting of the European Finance Association (Mannheim), 2017 SAFE Retreat Meeting (Frankfurt) as well as Martin Brown, William Diamond, Thomas Mosk, Giovanna Nicodano, Enrichetta Ravina and Oren Sussman for their insightful comments. We thank Nicola Mano and Silvia Dalla Fontana for their research assistance and the Research Center SAFE, funded by the State of Hesse Initiative for Research (LOEWE), for financial sponsorship of our research. We also thank Bundesbank and Auxmoney for providing us with access to their datasets. The views expressed in the paper are solely ours. We are responsible for all remaining errors.
} 


\section{Executive Summary}

In recent years, we have begun to observe the growth of the internet economy, which has progressively led to "crowd-based" platforms and the direct matching of lenders and borrowers. Via peer-to-peer (P2P) lending platforms the decision process of loan origination is given into the hands of private lenders and borrowers. This paper investigates how the $\mathrm{P} 2 \mathrm{P}$ lending competes with banks and specifically aims to answer the following questions: i. Under what circumstances do banks lose loans to P2P platforms? ii. What are the risk characteristics of the loans that migrate from banks to P2P platforms? iii. Are P2P platforms lending at higher or lower risk-adjusted interest rates than banks?

We develop a simple theoretical model, which gives three hypotheses we test empirically. Our results point that if some banks are subject to an exogenous increase in regulatory costs, and the unaffected banks are not sufficiently strong financially to replace the reduction in credit supply from the affected banks, banks in the aggregate will lose some loan market share to P2P lenders. Also, the loans made by P2P platforms are riskier than bank loans. Lastly, the risk-adjusted interest rates on bank loans are lower than those on bank loans.

One of the implications of our findings is that the advent of P2P lending may cause the banking sector to shrink, but also to be less risky and possibly more profitable in terms of risk-adjusted returns on assets. Whether this is underway on a broader scale in the credit market is an interesting topic for future research. 


\section{Introduction}

Motivation and Research Question: The contemporary theories of financial intermediation assign a pivotal role to banks as intermediaries between borrowers and savers (e.g., Coval and Thakor (2005), Diamond (1984), and Ramakrishnan and Thakor (1984)) 1] with some theories emphasizing the value of deposit-taking and lending in the same institution. $2^{2}$ Peer-to-peer (P2P) lending, which matches borrowers and lenders directly without reliance on deposits and eliminates an intermediating bank, has gained traction in recent years in both Europe and the U.S. (see, for example, Milne and Parboteeah (2016)). The two largest P2P platforms in the U.S., Lending Club and Prosper, originated over $\$ 11$ billion and $\$ 9$ billion in loans respectively as of the first quarter of 2017. A report from PricewaterhouseCoopers (2015) noted that the origination volumes of U.S. P2P lending platforms have grown an average of $84 \%$ per quarter since 2007. In the U.S. mortgages market, fintech lenders have increased their market share from $5 \%$ to $15 \%$ in conforming mortgages and to $20 \%$ in Federal Housing Association mortgages during 2007-2015 (see, e.g., Buchak, Matvos, Piskorski, and Seru (2017)). This increase in fintech and P2P lending is particularly interesting in light of the intertemporal behavior of new bank loans. This behavior is shown in Figure 1 which depicts the volume of new consumer loans in Germany provided by Auxmoney, the country's largest P2P platform, and by savings and cooperative banks.

[Figure 1$]$

As Figure 1 shows, new bank loans are trending downward while new P2P loans are trending upward, although the absolute volume of bank lending far exceeds that of P2P lending $3^{3}$ The commonly given explanations for the decline in bank lending relative to $\mathrm{P} 2 \mathrm{P}$ lending have to do with advances in information technology - those that diminish the relative advantage of banks and a heavier post-crisis regulatory burden on banks $4^{4}$

\footnotetext{
${ }^{1}$ In these theories, banks either provide valuable screening to enhance investment efficiency (e.g., Coval and Thakor (2005) and Ramakrishnan and Thakor (1984)) or more effectively collect repayment from borrowers (e.g., Diamond (1984)). The growth of fintech raises the question of whether these advantages have declined.

${ }^{2}$ See, for example, Donaldson, Piacentino, and Thakor (2018). In their general equilibrium theory of banking, banks create funding liquidity with universal risk neutrality, wherein aggregate initial investment of the economy in real projects exceeds the entire endowment of the economy. Deposit taking is necessary but not sufficient for bank liquidity creation. Rather the bank must accept deposits and make loans to create funding liquidity.

${ }^{3}$ Our focus is not on the levels of lending, but rather the interaction between P2P lending and bank lending.

${ }^{4}$ In the rest of the paper, we refer to bank and P2P lending as new loans provided by them in a certain period, not the actual stock of loans.
} 
Regardless of the underlying drivers and the observation that $\mathrm{P} 2 \mathrm{P}$ lending volume is only a relatively small fraction of bank lending volume, these time series patterns in lending raise interesting questions about the nature of the competition between $\mathrm{P} 2 \mathrm{P}$ lending and (intermediated) bank lending. Under what circumstances do banks lose loans to P2P platforms? What are the risk characteristics of the loans that migrate from banks to P2P platforms? Are P2P platforms lending at higher or lower risk-adjusted interest rates than banks?

What We Do: Our main goal in this paper is to address these questions empirically. As motivation for the hypotheses we test, we develop a simple theoretical model of bank and P2P lending. Banks in this model are intermediaries between depositors and borrowers and thus finance loans with deposits and their own equity. Deposits provide valuable liquidity services to depositors $5^{5}$ The leverage on the bank's balance sheet creates a risk-shifting distortion that must be attenuated with sufficient bank equity. Each bank also has to incur a regulatory intermediation cost, which is the price of having access to profitability-enhancing deposits. In contrast, a P2P platform is a nonintermediated lender that finances its loans with money from investors. Following Philippon (2016), we view P2P loans as being all-equity financed - i.e., the platform has no leverage of its own. Access to leverage via rent-producing deposits is a key competitive advantage of banks, so our model implies that when this advantage is diminished, P2P lenders will gain market share.

Main Results: The model yields the following results that serve as predictions that we test:

1. If some banks are subject to an exogenous increase in regulatory costs, and the unaffected banks are not sufficiently strong financially to replace the reduction in credit supply from the affected banks, banks in the aggregate will lose some loan market share to P2P lenders;

2. The loans made by P2P platforms are riskier than bank loans;

3. The risk-adjusted interest rates on bank loans are lower than those on bank loans.

We confront these predictions with data on P2P and bank lending in Germany. The data on P2P lending are provided by Auxmoney, which is the largest and oldest P2P lending platform for consumer credit in Germany. Data on bank lending are provided by the Deutsche Bundesbank. That is, we focus on the impact of higher regulatory costs as well as the presence of P2P lenders

\footnotetext{
${ }^{5}$ In the context of the Merton and Thakor (2018) framework, we view these depositors as "customers" who receive liquidity services in addition to deposit interest, and shareholders as "investors" who care only about their expected pecuniary return.
} 
on (i) new lending by banks and (ii) new loans by P2P lenders.

Because of differences between $\mathrm{P} 2 \mathrm{P}$ and bank lending in terms of origination, we compare the two datasets by examining risk and interest rate differences. Unlike previous studies, our database includes detailed information on interest rates for new loans as well as the risk profiles of P2P and bank loans. Using German rather than U.S. data has some advantages ${ }^{6}$ First, the consumer lending market in the U.S. is very heterogeneous - it includes not only banks and P2P lending platforms but also nonbank lenders like payday and title lenders. By contrast, consumer lending in Germany is primarily done by banks, and the Bundesbank provides good bank-level data. Second, P2P lending platforms in the U.S. do not serve subprime borrowers. Lending Club and Prosper apply minimum FICO score cutoffs of 660 and 640, respectively, to define credit-eligible borrowers; subprime borrowers typically have scores below 600. In Germany, such restrictions do not exist, and subprime borrowers are also served by P2P lenders. Third, our data include interest rates on new loans, which permits a comparison of rates charged on bank loans and P2P loans.

Finally, we focus on regional banks (i.e., saving banks (Sparkassen) and cooperative banks (Volksbanken)). In Germany, these banks have geographical restrictions, which permits a relatively clear analysis at the bank-state level. Moreover, their primary mandate is to provide credit for the local economy, which abstracts from other issues global banks might have and is closer to the bank described in our model.

The predictions of the theory are supported by our empirical results. In order to provide causal evidence for our key result (Prediction 1), we use a quasi-natural experiment, in which capital requirements for some banks - and hence their regulatory costs - increased unexpectedly due to new regulation. The experiment we look at is the 2011 European Bank Authority (EBA) capital exercise, which occurred in October 2011, a few months after the 2011 stress test and subsequent failure of Dexia bank. The capital exercise required participant banks to reach and maintain a $9 \%$ core tier 1 capital ratio by the end of June 2012.7 Two large Landesbank in Germany had capital ratios below this threshold: NordLB and HELABA. Consequently, NordLB had to increase its

\footnotetext{
${ }^{6}$ Because we use German data, one may question the external validity of our analysis. However, our theoretical model is free of any specific institutional features of the German credit market, so our predictions are generally valid in any setting in which banks face regulatory costs that exceed those of $\mathrm{P} 2 \mathrm{P}$ lenders and in which banks have a deposit-related funding advantage. Thus, we believe external validity of our results is not a concern.

${ }^{7}$ In Germany, participant banks were: Deutsche Bank, Commerzbank, Landesbank Baden-Württemberg, DZ Bank, Bayerische Landesbank, Norddeutsche Landesbank, Hypo Real Estate Holding, WestLB, HSH Nordbank, Landesbank Hessen-Thüringen (HELABA), Landesbank, DekaBank, and WGZ Bank.
} 
capital as a percentage of total assets by $2.99 \%$ (from $6.01 \%$ to $9 \%$ ) and HELABA had to increase its by $2.67 \%$ (from $6.33 \%$ to $9 \%$ ). Both represented substantial increases. Landesbank are also known as the "central bank" of savings banks and they are jointly owned by state governments and local savings banks. NordLB covers savings banks in Lower Saxony, Saxony-Anhalt, and MecklenburgWestern Pomerania, whereas HELABA covers savings banks in Hesse and Thuringia 8 We follow Puri, Rocholl, and Steffen (2011) and link the savings banks to their respective Landesbank. When a Landesbank is required to raise more capital, the savings banks of these states are also faced with higher regulatory costs due to their links with their Landesbank since much of the additional capital is provided by their local savings banks. This has two effects on the savings banks that work in the same direction to reduce lending by these banks. One effect is direct - these banks are using loanable funds to purchase equity in their Landesbank rather then lending the money. The other effect is indirect - the equity investment increases the risk of the savings banks and requires a higher capital ratio, which de facto increases regulatory costs.

Thus, our empirical strategy is to test whether saving banks linked to NordLB and HELABA visa-vis other saving banks and cooperative banks decreased their lending after the capital exercise 9 Moreover, we test (i) if $\mathrm{P} 2 \mathrm{P}$ lending rose more in those states, and (ii) whether the P2P market share gain was larger when the unaffected banks in the region were financially weaker (lower capital ratios) and hence less capable of making up for the reduced credit supply from the affected banks.

The capital exercise is a useful shock because it is exogenous to $\mathrm{P} 2 \mathrm{P}$ lending and any pre-shock actions of affected banks. We exploit this exogenous variation in the EBA bank selection rule and use a difference-in-differences (diff-in-diff) approach to identify the effect of the capital exercise on (i) overall bank lending in affected states, and (ii) Auxmoney lending activity in affected states.

We find that overall bank lending decreases in states where banks affected by the EBA exercise are present - affected banks reduced their lending more than unaffected banks in these states. Auxmoney also increased its lending in the treated states, and increased it by more if the unaffected banks in these states had low capital ratios.

\footnotetext{
${ }^{8}$ In its 2012 Annual Report, NordLB describes its sources of capital to meet the higher requirements. They included the Association of Savings Banks in Lower Saxony; the Savings Banks Holding Association in Saxony-Anhalt; and the Special Purpose Holding Association of Savings Banks in Mecklenburg-Western Pomerania, State of Lower Saxony, State of Bremen. The form was cash injection and conversion of silent participations and other capital instruments.

${ }^{9}$ The impact of higher capital requirements on bank lending has been examined in numerous papers. See, for example, Gropp, Mosk, Ongena, and Wix (2018), who specifically examine the credit supply effect of the EBA exercise.
} 
To gain further insight into the effect of $\mathrm{P} 2 \mathrm{P}$ lending, we examine whether the decline in bank lending in the regions with treated banks was greater when borrower awareness was greater. We do this by examining the internet search behavior of consumers in the period preceding the capital exercise and document that Auxmoney experienced a larger increase in loan volume when consumers had searched more for the word "Auxmoney" prior to the capital shock - i.e., when there was greater pre-shock consumer awareness of Auxmoney.

Related Literature: Although P2P lending, in its present form, is a relatively recent phenomenon that started in 2005 with the launch of Zopa, research interest has been growing after Prosper (a competitor of Zopa) made its entire platform's data available in 2007; see, for example, Pope and Sydnor (2011), Lin, Prabhala, and Viswanathan (2013), and Morse (2015). Most of the investors are now hedge funds and large institutions 10

Also relevant is the young but growing literature on fintech, to which P2P lending represents one of the components. Examples are Philippon (2015, 2016), Greenwood and Scharfstein (2013), and Buchak, Matvos, Piskorski, and Seru (2017). Philippon (2015) documents that despite advances in financial technology, the cost of financial intermediation has remained relatively constant over time. Philippon (2016) argues that fintech can bring about efficiency-enhancing structural change in the financial services industry, but that political economy factors are likely to impede this. Greenwood and Scharfstein (2013) emphasize that the growth in the financial industry in recent years has been driven mainly by the growth of asset management and household credit, and that shadow banking activities, such as P2P lending, were significant facilitators of the increase of household credit. Buchak, Matvos, Piskorski, and Seru (2017) find that fintech firms set interest rates that are more predictive of ex post default rates than rates set by banks for the U.S. residential mortgage market, and suggest that this may reflect the superior ability of fintech lenders to analyze big data.

Our paper differs from this literature in various ways. First, we develop a theoretical model in which competition from $\mathrm{P} 2 \mathrm{P}$ lenders, interbank competition, intermediation costs for banks and their role in providing liquidity services to depositors, as well as bank leverage all interact to generate predictions about the kinds of loans that will migrate from banks to P2P lending platforms. Second, we document - consistent with the predictions of the model - that when banks are faced

\footnotetext{
${ }^{10}$ Buchak, Matvos, Piskorski, and Seru (2017) point out that many of these institutions are the recipients of government safety nets, protection, and subsidies, which raises concerns about risk spillover implications.
} 
with higher regulatory costs, the riskiest bank loans will migrate to $\mathrm{P} 2 \mathrm{P}$ lenders first, causing both a decline in average risk in bank lending as well as a decline in overall bank lending, and that this happens more when the unaffected banks in the region are not financially strong and consumers are more aware of P2P lending. Third, we also document that P2P loans have lower risk-adjusted interest rates than banks 11

A contemporaneous related paper is Tang (HEC Paris 2018) which also examines whether P2P lending is a substitute for or complement to bank lending. In a conceptual framework with banks and P2P lenders coexisting in the market, the author derives testable hypothesis. Specifically, when there is a negative shock to bank credit supply, whether the quality of the $\mathrm{P} 2 \mathrm{P}$ borrower pool worsens or improves depends on whether bank and P2P lending are complements or substitutes. Using a change in US accounting rules for banks as a negative shock to bank credit supply, the paper shows that $\mathrm{P} 2 \mathrm{P}$ lending in the US is a substitute for bank lending in that it serves inframarginal bank borrowers, but it is a complement for small loans. Apart from the obvious difference in German versus US data, there are three key differences between the two papers. First, we develop a theoretical model of bank capital structure with endogenous bank and P2P lending choices that generates predictions we test. Second, we use a different shock to bank capital that affected banks heterogeneously and which allows us to examine the impact on aggregate bank lending, on P2P lending and associated reallocation effects. Third, we focus on a different set of issues, including pricing and default risk differences between banks and P2P platforms and the effect of mediating variables like bank capital and consumer awareness of P2P lending.

The rest of the paper is organized as follows. Section 2 presents the theoretical model. Section 3 describes the data. Section 4 presents the empirical findings. Section 5 concludes. All proofs are in the Appendix.

\section{Theory and Predictions}

In this section, we develop a simple theoretical model that is primarily designed to generate testable predictions about how $\mathrm{P} 2 \mathrm{P}$ lenders and banks compete and the implications of this for bank lending.

\footnotetext{
${ }^{11}$ The reason for this, in our theory, is different from the screening advantage for P2P lenders from the more effective analysis of big data suggested in Buchak, Matvos, Piskorski, and Seru (2017).
} 


\subsection{The Model}

Consider an economy in which all agents are risk neutral and the riskless rate is zero. There are banks, each of which has a borrower. For each borrower, there is always the possibility that a competing bank will arrive to bid for its business. For a competing bank, the cost of acquiring a borrower who is presently with another bank is $\widetilde{\alpha}>0$, a random variable. The realization of $\widetilde{\alpha}$, which we shall refer to as $\alpha$, becomes common knowledge at $t=0$ before competition begins. The variable $\widetilde{\alpha}$ is meant to represent the cost of prying away a borrower who has a loan from the incumbent bank. Similarly, a P2P platform also faces the same borrower acquisition cost $\widetilde{\alpha}$ in prying away a borrower from another bank.

The sequence of events is as follows. There are two dates: $t=0,1$. At $t=0$, the bank has a borrower who needs a loan of $L>0$.

The winning bank contracts with the borrower to repay $L_{R}$ at $t=1$ in exchange for a loan of $L$ at $t=0$. Once $L_{R}$ is determined, the bank determines its capital structure for financing the loan. At $t=1$, the borrower's project (financed with the loan) either pays off or not. The loan is repaid in full if the project pays off, and it defaults if the project fails.

Intermediation Cost: In exchange for being given access to deposit funding, banks must abide by regulations and agree to be supervised by regulatory authorities. Without specifying the details of these regulations, we stipulate that the "regulatory cost of intermediation" to the bank due to this is $K>0$. We assume that the social cost of bank failure is $\Omega(D)>0$, which is increasing and convex in $\mathrm{D}^{12}$ The desire to minimize this cost can cause the regulator to supervise banks, impose capital requirements, etc., and this can generate a regulatory cost $K$ for banks. Note that banks will not internalize $\Omega$ in their capital structure or lending decisions.

Loan Types: There are two good loans of varying risk: $g$ and $G$. The $g$ loan is associated with a borrower whose project pays off $\widehat{x}$ with probability (w.p.) $q \in(0,1)$ and 0 w.p. $1-q$. The maximum pledgeable cash flow that this borrower has to repay the loan is $x \in(0, \widehat{x}]$. The $G$ loan is associated with a borrower whose project pays off $\widehat{x}$ w.p. $p$ and 0 w.p. $1-p$. The maximum pledgeable cash flow to repay the loan is $x$ for this borrower as well. The payoffs on $G$ and $g$ are random variables. Whether the bank has $g$ or $G$ is exogenously specified for now ${ }^{13}$ In the cross-

\footnotetext{
${ }^{12}$ The assumption that $\Omega(D)$ is increasing in $D$ is motivated by the analysis in Merton and Thakor (2018)

${ }^{13}$ Later we will discuss what happens if the bank has both $G$ and $g$.
} 
section of banks, some banks have $g$ and some banks have $G$. Regardless whether the bank has $g$ or $G$, it has the option to unobservably invest instead in a loan, call it $B$, that generates a private benefit of $\Pi>0$ for the bank insiders (this is the manager who is also the inside equityholder) but no contractible payoff for outside financiers - i.e., the depositors ${ }^{14}$. This kind of moral hazard in lending is similar to that in Holmstrom and Tirole (1997). We assume:

$$
\begin{gathered}
p>q \\
\Pi<L<q x-K
\end{gathered}
$$

This means that both $g$ and $G$ are socially efficient, whereas $B$ is not. The competitive structure of the loan market is similar to that in Holmstrom and Tirole (1997) in that the incumbent bank can set the borrowers' repayment, $L_{R}^{i}$, on loan $i \in\{g, G\}$ equal to the pledgeable cash flow, $x$, on the project. However, if a competing bank arrives, then the loan repayment will have to be set to match that offered by the competing bank - i.e., $L_{R}^{i}=\min \left\{x, \widehat{L}_{R}^{i}\right\}$, where $i \in\{g, G\}$ and $\widehat{L}_{R}^{i}$ is the loan repayment the incumbent bank must offer when there is a competing bank for loan $i$.

The Bank's Financing Choices: The bank can finance the loan with any combination of deposits and (inside) equity. Let $E$ denote (inside) equity ${ }^{15}$ raised at $t=0$ and $D$ denote deposits raised at $t=0$, to finance loan $i \in\{g, G\}$. Then

$$
D^{i}+E^{i}=L
$$

Let $D^{i}=\bar{D}^{i}$ if no competing bank arrives and $D^{i}=\widehat{D}^{i}$ if a competing bank arrives. Deposits are uninsured. Since the bank's capital structure decisions are made at $t=0$ after the terms of lending are known, depositors can set the bank's repayment, $D_{R}^{i}, i \in\{g, G\}$, after observing these terms. Let $D_{R}^{i}=\bar{D}_{R}^{i}$ when there is no competing bank and $D_{R}^{i}=\widehat{D}_{R}^{i}$ when there is a competing bank. All corresponding values for the competing bank will be designated with a tilde - i.e., $\widetilde{D}^{i}$, $\widetilde{D}_{R}^{i}, \widetilde{L}_{R}^{i}, i \in\{g, G\}$. See Table 1 for a summary of the notation that we use in the model.

\section{[Table 1}

\footnotetext{
${ }^{14}$ There are many ways to think about this loan. For example, it could be a loan to a family member or a friend.

${ }^{15}$ We are not addressing in this context the agency problem between managers and equityholders, and we simply assume that they are the same.
} 
Liquidity Value of Deposits: Depositors derive a liquidity benefit of $\gamma>0$ per dollar of deposits. There is now an extensive literature on the microfoundations of this assumption 16

P2P Platforms: A P2P lending platform is a nonintermediated form of lending that links investors directly to borrowers via the platform. As Philippon (2015) points out, this is nonleveraged lending since the platform itself has no leverage and the claims of investors are direct (equity) claims on the loan cash flow. This has three implications. First, there is no asset-substitution moral hazard in terms of the platform unobservably investing in $B{ }^{17}$ Second, the platform does not have access to deposits, so all its financing comes from investors (not "customers"). Third, the platform does not incur the intermediation cost $K$ that a bank incurs. All external providers of finance - depositors and investors - are competitive pricetakers and thus their claims are priced to give them an expected return of zero (the riskless rate).

The time line describing the sequence of events is summarized in Figure 2

[Figure 2

\subsection{Analysis}

We will first consider the case in which there are no P2P lenders, so there is only interbank competition. We will show that in this case, no bank will lose its borrowers to another bank, so the main effect of interbank competition is to reduce loan prices. In what follows, we do not impose a regulatory capital requirement on banks, but we later discuss the effect of imposing such a requirement.

We begin by establishing the first-best, in which the lender's project choice is observable and can be contracted upon. Thus, the $B$ project is never chosen. The first best essentially solves $\max _{i \in\{g, G\}}\left\{V_{i}\left(D_{i}^{*}\right)-\left[1-S_{i}\right] \Omega\left(D_{i}^{*}\right)\right\}$, where $V_{i}\left(D_{i}^{*}\right)=S_{i}\left[L_{R}^{i}-D_{R}^{i}\right]-E$ and $D_{i}^{*}$ is the solution to $D_{i}^{*} \in \arg \max _{D}\left\{V_{i}\left(D_{i}\right)-\left[1-S_{i}\right] \Omega\left(D_{i}^{*}\right)\right\}$, subject to $S_{i}\left[L_{R}^{i}-D_{R}^{i}\right]-E-K \geq 0$ and the deposit pricing constraint $D^{i}=S_{i}\left[D_{R}^{i}+\gamma D^{i}\right]$. Here $S_{i}=p$ if $i=G$ and $S_{i}=q$ if $i=g$.

\footnotetext{
${ }^{16}$ For example, Merton and Thakor (2018) view bank depositors as "customers" who receive nonpecuniary service benefits from which they derive positive utility; these are benefits that do not accrue to the investors in the bank. Diamond and Dybvig (1983) view the liquidity benefits as being synonymous with consumption smoothing. Donaldson, Piacentino, and Thakor (2018) view these as stemming from a wealth-safeguarding advantage possessed by the bank.

${ }^{17}$ In our model, the bank would never invest in $B$ if it was all-equity financed.
} 
In the second best, the bank ignores the social cost $\Omega$ and solves the following problem at $t=0$ if it has $G$ :

$$
\max _{D} p\left[L_{R}^{G}-D_{R}^{G}\right]-E
$$

subject to:

$$
\begin{gathered}
p\left[L_{R}^{G}-D_{R}^{G}\right]-E-K \geq 0 \\
p\left[L_{R}^{G}-D_{R}^{G}\right] \geq \Pi \\
D^{G}=p\left[D_{R}^{G}+\gamma D^{G}\right] \\
D^{G}+E^{G}=L
\end{gathered}
$$

The objective function in (4) is the net present value (NPV) to the bank's shareholders, who are choosing their capital structure at $t=0$ to maximize this NPV. (5) is the bank's participation constraint, (6) is the incentive comparability (IC) constraint to ensure that the bank prefers $G$ to $B$, (7) is the depositors' pricing constraint that links the amount of deposits raised at $t=0$ to the deposit repayment obligation at $t=2$, and (8) is simply the bank's balance sheet identity. If the bank has $g$, then we simply replace $p$ by $q$ and $D_{R}^{G}$ by $D_{R}^{g}$.

In focus of the cases of interest, we now impose the following restrictions on the exogenous parameters:

$$
\begin{gathered}
\frac{\Pi+L[1-p \gamma]}{p}>x>\max \left\{\frac{\Pi+L[1-p \gamma]-[\Pi-\{\alpha+K\}][1-p \gamma]}{p}, \frac{L+\alpha+K}{q}\right\} \\
\Pi>\max \{K+\alpha, L q \gamma+\alpha\}
\end{gathered}
$$

Essentially, (9) says that $x$ cannot be too big or too small. If it is too big, the asset-substitution moral hazard problem becomes irrelevant and we will get the first-best solution. If it is too small, no competing bank will find it profitable to pry a $g$ borrower away from an incumbent bank. Equation (10) simply asserts that investing in $B$ would allow the bank to overcome the cost of intermediation and the cost of poaching a borrower from another bank.

Proposition 1. In the second-best case, if no competitor arrives, the incumbent bank will choose a deposit level $\bar{D}^{i} \in(0, L)$ and equity capital $\bar{E}^{i}=L-\bar{D}^{i}$ to finance itself (where $i \in\{g, G\}$ depending 
on which socially efficient loan the bank has). If a competitor arrives, the incumbent bank will choose deposits of $\widehat{D}^{i} \in(0, L)$ and equity capital $\widehat{E}^{i}=L-\widehat{D}^{i}$, where $\widehat{D}^{i}<\bar{D}^{i} \forall i \in\{g, G\}$. Moreover, $\bar{D}^{G}>\bar{D}^{g}$ and $\widehat{D}^{G}>\widehat{D}^{g}$. Proof in Appendix.

In the second best, the bank has to post some equity capital as "skin in the game" in order to assure depositors that it will invest in the socially efficient loan $(g$ or $G)$. The worse the incentive compatibility problem, the more equity capital it must post. If no competitor arrives, the bank can charge a higher loan price on either $g$ or $G$, so the incentive compatibility problem is less severe and the bank can finance with more deposits. Also, since $G$ is valued higher than $g$, the incentive compatibility problem with $G$ is less severe and a higher level of deposit financing can be used. Competition, therefore, reduces the bank's profitability both due to its direct effect on the loan interest rate the bank can charge (e.g., the loan repayment) and its indirect effect because the lower loan interest rate decreases the leverage the bank can optimally finance itself with.

Note that the bank's choice of capital structure does not internalize the social cost of bank failure, $\Omega$. So, if we were to solve for the (constrained-efficient) socially optimal capital structure that could be the regulatory capital requirement, it may call for a higher level of capital than in Proposition 1, as shown below.

Lemma 1. Suppose the regulator is solving the bank's problem in (4) - (8) but is taking into account the social cost $\Omega$. Then the constrained social optimum for the regulator is to invest in the socially efficient ( $g$ or $G$ ) loan that it has available and to choose a deposit level lower than or equal to $\bar{D}^{i}$ (with competitive entry) and lower than or equal to $\widehat{D}^{i}$ (without competitive entry). Proof in Appendix.

Our next result is about competitive interactions among banks.

Corollary 1. No competing bank will ever successfully take a borrower away from an incumbent bank, as long as both face the same $K$. The loan-repayment obligation will be lower when a competing bank arrives than when it does not. Proof in Appendix.

This result is straightforward. All banks are identical, but to take a borrower away from another bank, the competing bank has to incur a "poaching cost" of $\alpha$, so the incumbent can match the competing bank's best offer and still make a positive expected profit on this loan. The 
only exception is if the competing bank has a lower $K$ and the difference between the incumbent bank's $K$ and the competing bank's $K$ is greater than the competitor's $\alpha$.

We now introduce competition from P2P lenders. It is convenient to define

$$
\begin{aligned}
& A_{1} \equiv K[1-p \gamma]-p \gamma[L-\Pi] \\
& A_{2} \equiv K[1-q \gamma]-q \gamma[L-\Pi]
\end{aligned}
$$

The following result can now be proved.

Proposition 2. If the realized $\alpha \in\left[A_{1}, A_{2}\right)$, then banks with $g$ loans lose their borrowers to P2P lenders, but banks with $G$ loans do not experience any loan migration. If $\alpha \geq A_{2}$, then no banks lose any loans to P2P lenders. When P2P lenders arrive to compete with banks, the banking system is more likely to lose $g$ loans than $G$ loans, and for $\alpha<A_{2}$, growth in P2P lending will be correlated with a decline in bank lending. Proof in Appendix.

The key to this result is that the $G$ loan requires less capital for the bank to finance it. Hence, its profitability to the incumbent bank always exceeds the profitability of the $g$ loan, and an incumbent bank competes more aggressively with P2P lenders for this loan than for the $g$ loan. Whether banks lose $G$ loans to the P2P lenders depends on the poaching cost, $\alpha$, that the P2P lenders realize. If this poaching cost is very low, then all banks stand to lose loans to P2P lenders, and if it is very high, no banks lose loans. For intermediate values of $\alpha$, banks lose their riskiest loans to P2P lenders, and P2P loan growth is at the expense of bank loan growth. Note also that when loans migrate to $\mathrm{P} 2 \mathrm{P}$ lenders, it is because the realized poaching cost, $\alpha$, is low enough to overcome the combination of the bank's deposit-based funding cost advantage and its intermediation cost disadvantage. Thus, risk-adjusted interest rates on P2P loans are lower than what they would be had these loans stayed on the banks' books. In practice, banks face capital requirements when they put loans on their books. If we had capital requirements in our model and there was an exogenous shock that required some banks to post capital beyond what was needed for incentive compatibility, then our analysis implies that those banks would lose more loan market share to P2P lenders than banks that did not face higher capital requirements. Similarly, if a bank faces an exogenous shock that increases $K$, it will lose market share to P2P lenders and banks that do not experience a higher 
$K$. This is summarized below:

Corollary 2. If a bank experiences an increase in $K$ (or regulatory capital requirements beyond the level needed for incentive compatibility), the measure of $\left[A_{1}, A_{2}\right)$ increases, increasing the probability that the bank will lose its $g$ loan to P2P lenders. Moreover, the incumbent bank may also lose its $g$ loan to another bank that has not experienced an increase in $K$ if the incumbent bank faces a sufficiently large increase in $K$ or regulatory capital requirements. Proof in Appendix.

If there are no $\mathrm{P} 2 \mathrm{P}$ lenders, then an increase in $K$ or capital requirements for some banks and not for others would have no perceptible effect on overall bank lending, since loans will simply shift from some banks to others ${ }^{18}$ But if it is $\mathrm{P} 2 \mathrm{P}$ lenders that take some loan volume away from the affected banks, then overall bank lending will fall. Thus, if we can identify an exogenous shock to $K$, it may help us identify a causal link between the presence of $\mathrm{P} 2 \mathrm{P}$ lenders and bank lending.

Which loans are likely to migrate to P2P lenders? Note that condition (2) implies that the loan has a positive NPV to the bank. If there are loans for which $q x>L>q x-K$, then these loans will be positive-NPV for P2P lenders but negative-NPV for banks. Hence, if banks face a sudden increase in regulatory costs that leads to $L>q x-K$ for some loans, then these loans will migrate to P2P lenders, unless the banks unaffected by the increase in $K$ step in and satisfy the loan demand not being met by the treated banks. But if the unaffected banks are capital constrained, then they may not step into the vacuum created by treated banks, and P2P lending will grow at the expense of overall bank lending.

Moreover, to the extent that regulators are attempting to control bank risk, $K$ may be higher for riskier loans, so these loans are most likely to be taken away by P2P lenders when they gain market share. This discussion leads to the following corollary.

Corollary 3. If some banks experience an increase in $K$ that makes $g$ loans unprofitable for them, these loans may be picked up by unaffected banks if they are not capital constrained. If the unaffected banks are capital constrained and cannot expand their lending, these loans will go to P2P lenders, and overall bank lending will decline.

\footnotetext{
${ }^{18}$ Starting with an equilibrium in which banks are making $g$ and $G$ loans, if some banks experience an increase in $K$ and others do not, the banks that do not experience an increase in $K$ will always outcompete P2P lenders in taking loan volume away from the adversely affected banks if poaching costs are equal for P2P lenders and unaffected banks. Thus, in our model, unaffected banks will let business go to P2P lenders only if they are somewhat constrained.
} 
Also, we have not considered a bank that has both $g$ and $G$ loans in its portfolio. We have conducted this analysis, but do not present it here because all of our predictions are sustained, albeit at the cost of more algebraic complexity. The following observations emerge from that analysis:

- The amount of equity capital the bank needs to keep against a two-loan portfolio consisting of $g$ and $G$ is lower than the sum of the equity capital levels of two separate banks, one with $g$ and one with $G$.

- When faced with competition for a loan from a P2P lender, the bank will be willing to give up $g$ before it gives up $G$.

- It will be more difficult (will require a lower $\alpha$ of realization) for a P2P lender to take a $g$ loan away for a bank when a bank has both $g$ and $G$ loans than when it has only $g$.

The intuition for these results comes from the fact that when the bank already has $G$ on its balance sheet, $g$ is more valuable as an addition than if the bank has only $g$, since the diversification across $g$ and $G$ increases the expected value of liquidity services to depositors, reducing the bank's cost of funding and making the incentive compatibility condition easier to satisfy. Thus, in this more complicated case of the incumbent bank possessing both $g$ and $G$ loans, our results are strengthened. Note that if banks are making both $g$ and $G$ loans and they lose $g$ loans, their average profitability in lending will improve even though overall lending by banks declines. Further, if bank deposits are insured and deposit insurance is underpriced, our results will be strengthened, and they will be unaffected with actuarially fairly priced insurance.

Our analysis generates the following hypothesis that we confront with the data:

Hypothesis 1: There is a negative relationship between bank lending and P2P lending, and banks lose market share to $\mathrm{P} 2 \mathrm{P}$ lenders when banks are faced with an exogenous increase in regulatory costs. The greater borrowers' awareness of P2P, the bigger the loss of bank market share. Similarly, the more unaffected banks are capital constrained, the bigger the loss of banks' market share.

Hypothesis 2: P2P loans are riskier than bank loans.

Hypothesis 3: The risk-adjusted interest rate on bank loans is higher than the risk-adjusted interest rates on $\mathrm{P} 2 \mathrm{P}$ loans. 


\section{Data Description}

The data sources used in our study are (i) Auxmoney for data on P2P lending; (ii) the Deutsche Bundesbank (Interest Rates Statistics) for data on bank lending; (iii) Schufa for data on credit ratings; (iv) the Deutsche Bundesbank (Balance Sheet Statistics) for data on loan loss provisions.

Auxmoney is the oldest and largest P2P lending platform in Germany. According to its website, from the day it began business in 2007 until late 2015, the total volume of credit provided was $€ 219$ million in 39,090 projects, with an average nominal interest rate of 9.65\%.

Auxmoney provided us with two different datasets. The first includes all loans divided by state between January 2010 and September 2014, with no maturity information. The second includes the average interest rate and the average credit rating represented by the Schufa score for each state per month 20

The Deutsche Bundesbank statistics used in this study are provided by two different datasets. The first is the Interest Rates Statistics (MIR, see Bade and Beier (2016) for further information on this data source), which is a stratified sample of the German banking sector used for supervisory activities and gives the amounts and the interest rates per bank and per month applied to nonconstruction consumer credit lines (outstanding and new business) for different maturities (overdraft, up to one year, and more than one year) ${ }^{21}$ The statistics are composed of monthly observations between January 2010 and September 2014. The second is the dataset from the Balance Sheet Statistics (BISTA, see Beier, Krueger, and Schaefer (2016) for further information on this data source), which gives information on write-ups and write-downs, from which we derive the banks' loan loss provisions.

Our analysis is at the bank-state level. The regional differentiation of bank loans is possible because of a feature of the German banking system: the presence of Sparkassen (savings banks) and Volksbanken (cooperative banks). Each bank is only present in one German state. Sparkassen are geographically restricted banks with a legal mandate to provide bank services to all creditworthy

\footnotetext{
${ }^{19}$ Schufa is a German private credit bureau with 479 million records on 66.2 million natural persons. Schufa provides credit ratings for each person requesting a loan and Auxmoney provides the Schufa score of each credit application.

${ }^{20}$ For reasons of data confidentiality, Auxmoney provides its credit intermediation by month and state only if five or more loans were made in that month in that state.

${ }^{21}$ The Interest Rates Statistics (MIR) is the German part of a larger dataset that is used by the ECB for regulatory purposes. It does not cover the whole German banking sector, only a stratified sample. For this reason, our sample does not cover all Sparkassen and Volksbanken in Germany, just the ones present in this data source.
} 
customers ${ }^{22}$ Volksbanken are cooperative banks (also geographically restricted) whose customers are members of an organizational structure that aims at credit facilitation. By focusing on those banks that are more readily comparable to Auxmoney, we avoid the inclusion of large commercial banks or any nonregional banks. Thus, there are 105 banks in our sample, and they hold loans of relatively small sizes. These banks are also used in Puri, Rocholl, and Steffen (2017) in their examination of how relationship information affects default risk.

Since we use data across different German states, we also provide data on the geographic distribution of consumer credit across states by banks and Auxmoney in Figure 3 . Each individual gray bar represents the share of bank credit provided in a specific state in relation to the total amount of bank credit provided in all states (in our sample of banks). Similarly, each single black-colored bar represents the share of $\mathrm{P} 2 \mathrm{P}$ credit provided in a specific state in relation to the total amount of $\mathrm{P} 2 \mathrm{P}$ credit provided in all states. For three states (Brandenburg, Saarland, and Thuringia), there is no information on Sparkassen credit, so these are excluded from our sample.

[Figure 3

Table 2 reports the descriptive statistics of the interest rates applied to new loans by banks and P2P lending during the period January 2011 to August 2014. The average interest rates across banks are $11.10 \%, 3.50 \%$, and $4.63 \%$ for overdrafts, short-term loans (less than a year maturity), and midterm loans (from one to five years maturity), respectively. During the same period, the average interest rate on $\mathrm{P} 2 \mathrm{P}$ loans is $12.82 \%$. Interest rates on $\mathrm{P} 2 \mathrm{P}$ loans are significantly higher than those on short- and midterm loans, but not significantly higher than those on overdrafts. In summary, this table shows that the mean Auxmoney interest rate is higher than the mean bank interest rate for any of the three categories.

\section{[Table 2}

Table 3 provides comparative descriptive statistics of the total volume of $\mathrm{P} 2 \mathrm{P}$ lending and the total volume of new loans per bank by different maturities (overdrafts, short-term loans, and midterm loans). The average total volume of new loans granted by Auxmoney per state per month is $€ 252,089$, substantially lower than the average monthly total new loan volume per bank per

\footnotetext{
${ }^{22}$ For further details on the Sparkassen structure, see Puri, Rocholl, and Steffen (2011).
} 
month, which is $€ 76.8$ million for overdraft loans, $€ 9.4$ million for short-term loans, and $€ 3.2$ million for midterm loans. This table shows that the mean size of Auxmoney is smaller than the mean size of any of the three bank loan categories. However, the standard deviation is much larger, indicating a higher intertemporal loan volume volatility for Auxmoney during the sample period.

[Table 3]

Auxmoney also provides us with the statistics of the distribution of its loan maturities as reported in Table 4. This table shows that the maturity of Auxmoney loans is between one and five years. The largest number of loans provided are the three-year loans $(3,292)$, and the smallest are the one-year maturity loans $(1,310)$. However, in terms of total volume, the largest volumes are for loans with four-year and five-year maturities. We include in our analysis all the three types of consumer loans provided by banks, since P2P loans are used for several purposes that include all three categories of loans that banks make.

\section{[Table 4}

We measure the default probabilities of Auxmoney borrowers by using the Schufa score data. Schufa score is the German consumer credit rating, the equivalent of FICO scores in the U.S. From the Schufa scores, we proxy for the default probabilities by using the transformation table provided by Korczak and Wilken (2010); see Table 5. This allowed us to match the Schufa scores and loan-default probabilities.

[Table 5$]$

Banks also have access to the Schufa scores of their clients, but this information is kept confidential. The only proxy we have for loan riskiness from the Deutsche Bundesbank data is the loan-loss provision. Whenever a bank expects a loan to not perform (typically, when it is 90 days overdue), it will write the loan down on its balance sheet and create a provision called a loan-loss allowance. Similarly, a loan can be written up if it was expected to default and was written down, but was paid in the end. In the BISTA of the Deutsche Bundesbank, loans are written up/down in full regardless of their recovery rate 23 . We use this information as a proxy for the loan-default probability, $\sigma$, defined as loan write-downs over outstanding loans:

\footnotetext{
${ }^{23}$ See, for example, Memmel, Gündüz, and Raupach (2015).
} 


$$
\sigma=\frac{\text { Loan write-downs }}{\text { Outstanding loan }}
$$

The results are summarized in Table 6, which provides the summary statistics of the default probabilities of bank loans and $\mathrm{P} 2 \mathrm{P}$ loans.

[Table 6]

As Table 6 shows, on average, $\mathrm{P} 2 \mathrm{P}$ borrowers have a default probability of $7.32 \%$. This is substantially higher than the default probabilities of $0.10 \%, 0.14 \%$, and $0.03 \%$ for overdraft, shortterm and midterm bank loans, respectively. The standard deviation of the default probability is also bigger for Auxmoney than for banks loans. A formal test of risk differences confirms that P2P loans have statistically significantly higher default probabilities than all categories of bank loans. In its yearly report on consumer credit risk in Germany, Schufa states that the overall probability of default across all German borrowers is $2.5 \% 24$ In the analysis, we perform a robustness check that our results hold even if we adjust the mean of our distribution.

\section{Empirical Findings}

The summary statistics presented above are broadly in line with the predictions of our theoretical model. In this section, we investigate formally the three hypotheses stated in Section 2 .

\subsection{Hypothesis 1: There is a negative relationship between bank lending and P2P lending, and banks lose market share to P2P lenders when banks are faced with an exogenous increase in regulatory costs.}

Figure 1 shows that the overall volumes of new bank loans and new P2P loans appear to be negatively related. In this section, we formalize the analysis. First, we present evidence that bank lending volume is negatively correlated with P2P lending volume. Second, we use a quasi-natural

\footnotetext{
${ }^{24}$ The difference between this and the average default probability in our sample likely reflects the fact that growth in $\mathrm{P} 2 \mathrm{P}$ lending is occurring with the acquisition of loans that are riskier than the average loan in the overall $\mathrm{P} 2 \mathrm{P}$ loan portfolio. This is consistent with P2P platforms peeling off the riskiest bank loans. Further, the large difference in the risk of $\mathrm{P} 2 \mathrm{P}$ and bank loans in our sample is also in part a reflection of the fact that Schufa score is an ex ante measure of default risk, whereas the way we measure the default risk of borrowers is ex post.
} 
experiment to show that when banks are faced with an exogenous increase in regulatory costs, $\mathrm{P} 2 \mathrm{P}$ lending increases.

\subsubsection{Relationship between bank lending and P2P lending. We investigate the relation-} ship between bank lending and Auxmoney lending using time and state fixed effects to account for timing within a business cycle and conditions related to local geography. Also, since every bank is physically constrained to operate within one state, we use the new credit supplied by all other banks in that state as a proxy for bank competition within the state, since this competition may influence the relation between bank lending and Auxmoney lending. We estimate:

$$
\log \left(L_{t, b_{j}}^{b a n k}\right)=\gamma_{1} \log \left(L_{t, j}^{P 2 P}\right)+\gamma_{2} \log \left(L_{t,-b_{j}}^{\text {bank }}\right)+\Delta_{j}+\Delta_{t}+\epsilon_{t, b_{s}}
$$

where $L_{t, b_{j}}^{b a n k}$ is the new-loan volume by bank $b_{j}$ (the subscript $j$ indicates that bank $b$ is active in

state $j$ ) at time $t, L_{t, j}^{P 2 P}$ is the new-loan volume by Auxmoney in state $j$ at time $t$, and $L_{t,-b_{j}}^{b a n k}$ is the sum of new lending by all other banks in state $j$ at time $t$.

Table 7 presents the results. The first regression shows that if we do not include time and state fixed effects, no significant relationship emerges. However, when we include both state fixed effects and time fixed effects, the relationship between bank lending and P2P lending is statistically significantly negative, as predicted by the theory. In all equations, lending by a bank in a given state is also negatively correlated with the sum of new lending provided by all the other banks in that state. These results provide support for our first hypothesis.

\section{[Table 7}

\subsubsection{Bank lending and P2P lending responses to higher regulatory capital require-}

ments: A quasi-natural experiment. In order to examine the impact of an exogenous increase in regulatory costs for banks on the relationship between bank lending and P2P lending, we use the 2011 EBA capital exercise as a quasi-natural experiment, in which bank capital requirements were exogenously shocked 25 We investigate whether Auxmoney significantly increases its new lending

\footnotetext{
${ }^{25}$ A similar quasi-natural experiment has been performed by Gropp, Mosk, Ongena, and Wix (2018) to investigate the bank response to higher capital requirements; it showed that affected banks increase their capital ratios not by increasing capital but by reducing their risk-weighted assets for corporate and retail exposures.
} 
in those states where some banks were affected by the EBA capital exercise.

The 2011 EBA capital exercise: The EBA published its capital exercise results on October 26, 2011, and it required banks to reach and maintain a 9\% core tier 1 capital ratio by the end of June 2012. This requirement represented an exogenous increase in bank regulatory costs. This shock is useful for our purposes for a number of reasons. First, the core tier 1 ratio of $9 \%$ required by the capital exercise is substantially higher than the $5 \%$ previously required. Second, the capital exercise was largely unexpected as the EBA had conducted the 2011 stress tests only a few months earlier (June 2011) and provided no indication of the subsequent capital exercise. Third, none of the banks in our sample (Sparkassen and Volksbanken) participated directly in the capital exercise. Each Sparkasse is linked to a Landesbank, and each Volksbank is linked to the DZ Bank 26 Landesbank and the DZ bank provide the banks access to international capital markets ${ }^{27}$ All Sparkassen of a given state are linked to the same Landesbank and all Volksbanken in Germany are linked to the DZ bank. The direct effect of the capital exercise was on some Landesbank, so the effect on the banks in our sample was indirect. This indirect effect is consistent with the assumption that the treated banks could not anticipate whether they would be affected by the capital exercise and were unlikely to have changed their lending behavior in anticipation.

The capital exercise forced two Landesbank, HELABA and NordLB, to raise additional capital equal to $2.67 \%$ and $2.99 \%$, respectively, of their assets. ${ }^{28}$ In its 2012 Annual Report, the NordLB quantifies its capital increase as $€ 2.56$ billion from outside sources including its associated Sparkassen and state governments (Lower Saxony, Mecklenburg-Western Pomerania, and SaxonyAnhalt), and $€ 638$ million from own sources. Economically, the link between Landesbank and Sparkassen comes from the ownership structure - i.e., Sparkassen partially own their respective Landesbank and vice versa. For example, Savings Banks and Giro Association of Hesse-Thuringia own $85 \%$ of HELABA. This means that Sparkassen have to contribute significantly to the recapitalization of their Landesbank. This has two effects on the lending by these banks. One effect is direct: these banks have to purchase the equity of their Landesbank rather than lending the money. The other effect is indirect: the equity investment increases the savings banks' risk and requires a

\footnotetext{
${ }^{26}$ See Puri, Rocholl, and Steffen $(2011)$ for a detailed description of the connections between Landesbank and Sparkassen.

${ }^{27}$ Some Landesbank covers more than one state, but in a given state there is only one Landesbank present.

${ }^{28}$ Note: The information used in this study regarding HELABA and NordLB was not provided by the Bundesbank, but comes from public data sources, including the EBA and Gropp, Mosk, Ongena, and Wix (2018).
} 
higher capital ratio. Thus, an exogenous increase in the capital required of Landesbank represents an exogenous decrease of funds that could be dedicated to lending and an increase in the regulatory costs faced by the Sparkassen - since their capital ratio increases, that also reduces their capacity to provide lending.

Empirical strategy: Our empirical strategy is to examine first whether the Sparkassen linked to HELABA and NordLB reduced their lending enough to cause the overall bank lending in those states to decline. In other words, we investigate whether all banks in the states where HELABA and NordLB are present (Hesse, Lower Saxony, and Mecklenburg-Western Pomerania) 29 have an overall lending reduction. Further, we test whether Auxmoney filled the vacuum by increasing its lending more in these states.

To analyze the overall impact of the EBA capital exercise on lending, we conduct two types of diff-in-diff analyses ${ }^{30}$ First, we sum up the volume of new loans over all banks in a given state and investigate whether, during the EBA capital exercise, the total volume of new bank lending declines more in the states where HELABA and NordLB are present than in the other states. Specifically, the first diff-in-diff model that we estimate is the following:

$$
\log \left(L_{t, s}\right)=\alpha_{1} \text { treated }_{s} * E B A_{t}+\alpha_{2} E B A_{t}+\alpha_{3} \text { treated }_{s}+\Pi W_{t, s}+u_{t, s}
$$

where $\log \left(L_{t, s}\right)$ is the logarithm of lending volume by banks in state $s$ in period $t$, treated is a dummy variable that identifies the treatment group - i.e., it is equal to one for the states where HELABA and NordLB are present, which we call treated states, and zero for all the other states, which we call control states. $E B A_{t}$ is the treatment time dummy that takes the value 1 from October 2011 onwards, and 0 prior to October 2011. $W_{t, s}$ is a vector of control variables, including the weighted average of interest rates on the new loans and risk in state $s$ at time $t$, and $u_{t, s}$ is the error term.

Second, to confirm that our results are robust even in a disaggregated form and not driven by the largest banks, we perform a similar estimation in the bank dimension. Instead of summing up lending by all banks in a given state, we estimate a similar diff-in-diff model at the individual bank

\footnotetext{
${ }^{29}$ HELABA and NordLB are also present in the states of Thuringia and Saxony-Anhalt, but the Bundesbank database on new bank loans does not provide any information about savings banks in these states, as we highlighted in Figure 3

${ }^{30}$ See also Cerqueiro, Ongena, and Roszbach (2016), who use a similar approach.
} 
level. In this setup, the treatment group is all banks (Sparkassen and Volksbanken) in states where HELABA and NordLB are present, which we call treated banks ${ }^{31}$ The control group consists of all other banks (i.e., Sparkassen and Volksbanken) in other states. The diff-and-diff model that we estimate is the following:

$$
\log \left(L_{t, b}\right)=\alpha_{1} \text { treated }_{b} * E B A_{t}+\alpha_{2} E B A_{t}+\alpha_{3} \text { treated }_{b}+\Pi W_{t, b}+u_{t, b}
$$

where $\log \left(L_{t, b}\right)$ is the logarithm of new-loans volume in period $t$ by bank $b$, treated $b$ is a dummy variable that identifies the treatment group - i.e., it is equal to 1 for all the banks (Sparkassen and Volksbanken) in the treated states. The control group consists of all the banks (Sparkassen and Volksbanken) located in the other states. The $E B A_{t}$ variable is the same as in equation (15), $W_{t, b}$ is a vector of control variables, including interest rates and risk at the bank level, and $u_{t, b}$ is the error term.

In order to check if Auxmoney increased its lending in states where overall bank lending decreased, we perform a diff-in-diff analysis on new Auxmoney lending. Similar to Equation (15), states where HELABA and NordLB are present are called treated states. The control group consists of all other states. The diff-and-diff model that we estimate is the following:

$$
\log \left(L_{t, s}^{P 2 P}\right)=\beta_{1} \text { treated }_{s} * E B A_{t}+\beta_{2} E B A_{t}+\beta_{3} \text { treated }_{s}+\Pi W_{t, s}^{P 2 P}+e_{t, s}
$$

where $\log \left(L_{t, s}^{P 2 P}\right)$ is the logarithm of new Auxmoney loan volume in state $s$ in period $t, E B A_{t}$ and treated $_{s}$ variables are the same as in equation $\sqrt{15}, W_{t, s}^{P 2 P}$ is a vector of control variables, including interest rates and risk of new Auxmoney loans in state $s$ at time $t$, and $e_{t, s}$ is the error term.

Data: Table 8 in Panel A shows summary statistics for the treatment and control groups before the treatment at the state level. For simplicity, we aggregate all three types of bank loans mentioned previously into one - i.e., our lending variable is the total of nonconstruction consumer loans by all banks in a given state ${ }^{32}$ Summary statistics at the state level indicate that treated banks have higher loan volume and higher loan interest rates than control banks and the difference is statistically significant at the $5 \%$ level. Moreover, the treated banks' loans are riskier than those

\footnotetext{
${ }^{31}$ Note that unaffected banks in treated states - i.e., Volksbanken - are considered treated banks in this estimation.

${ }^{32}$ We conducted the analysis separately for each loan type and all results are consistent with the ones presented.
} 
of the control banks, but the difference is not statistically significantly different from zero.

Panel B in Table 8 reports statistics at the individual bank level for banks in treated states and control states. The Panel shows that both new loan volume and risk are not statistically different across control and treated banks, but interest rates are higher for treated banks and the difference is statistically different from zero.

On the Auxmoney side (Panel C), the difference of log volume of new loans is not statistically significantly different across treated and control states. Interest rates are higher in the treated states than in the control states: $13.84 \%$ versus $13.69 \%$, with a difference of $0.15 \%$ that is statistically significantly different from zero. The risk is smaller in treated states than in the control states, with a difference of $0.67 \%$ that is statistically significantly different from zero.

In summary, this table shows that treated banks charge higher loan interest rates than control banks and the volume of new loans is higher for treated banks when aggregated at the state level, but there is no difference between treated and control states when disaggregated individual banklevel data are used. For Auxmoney, treated and control states have similar loan volumes, but treated states have less risky loans carrying higher interest rates.

\section{[Table 8}

Parallel trends: To check the parallel-trends assumption, we present Figure 4, which shows lending by banks over time for the two groups (treated and control) normalized to the value of 100 for the third quarter of 2011.

The figure shows that in treated states, the volume of new bank loans is similar to that in control states before the EBA capital exercise - i.e., until October 2011. This indicates that the parallel-trends assumption is valid. After the EBA capital exercise, the new-loan volume dropped both for control and treated banks, but it dropped more and faster in treated states than in control states. We also perform a formal parallel-trends test on the percentage change in bank lending, which confirms that the parallel-trends assumption holds.

\section{[Figure 4}

Similarly, we check the parallel-trends assumption with Auxmoney. Figure 5 shows Auxmoney credit provision for the two groups normalized to the value of 100 for the third quarter of 2011. 
It shows that the volumes of new Auxmoney loans in treated and control states exhibited parallel trends prior to the EBA capital exercise. After the EBA capital exercise, Auxmoney lending increases in both treated and control states. However, the increase is larger in treated states than in control states. In this case too, we perform a formal parallel-trends test, and confirm that the parallel-trends assumption is valid for the volume of new Auxmoney loans.

[Figure 5

Difference-in-differences analysis: We perform the diff-in-diff analyses presented in equations (15), (16) and (17). The estimations are reported in Table 9.

[Table 9]

The first three columns of Table 9 report the estimation results of Equations (15); columns (I), (II), and (III) show the results for the new-loan volume of banks without any fixed effects, with bank fixed effects, and with both bank and time fixed effects, respectively. The analysis shows that lending in the treated states after the EBA capital exercise declined more than in control states for the period after the EBA capital exercise. The coefficient is negative and significant for estimations with fixed effects and equal to -0.06 using state fixed effects and equal to -0.05 using state and time fixed effects. Thus, in the post-capital-exercise period, total bank lending in treated states declined more than in control states as already highlighted by Figure 4.

Next, we present the diff-in-diff estimation of loans equation (16). Results are reported in columns (IV), (V), and (VI) of Table 9. The coefficient of the interaction term, treated t $_{b} * E A_{t}$, is negative and significant in all the estimations and equal to -0.05 in the estimation with state and time fixed effects. This means that banks in treated states (both Sparkassen and Volksbanken) reduce their lending relative to banks in the control group after the 2011 capital exercise. This result is consistent with the view that total bank lending decreased - i.e., unaffected banks in treated states were unable to make up for the reduction in lending by the affected banks, confirming our previous result.

Finally, we estimate equation (17). Results are reported in columns (VII), (VIII), and (IX) of Table 9. As the table shows, P2P lending increased significantly in these states during this period. The coefficient of the interaction term is positive and significant at the $1 \%$ level and equal to 0.20 if 
we include state fixed effects and equal to 0.22 if we include state and time fixed effects. Therefore, consistent with our theoretical model, we find that P2P lending increased, with the largest increase occurring in the states where the treated banks were located.

Disaggregated diff-in-diff analysis: So far we have shown that total bank lending declined in treated states, but we did not distinguish between the savings banks that were affected by the EBA exercise (Sparkassen) and the others (Volksbanken). Therefore, we perform two other diff-indiff analyses. The first focuses on new Sparkassen lending in treated states and the second focuses on new Volksbanken lending in treated states. We find that the Sparkassen linked to HELABA and NordLB decreased their lending after the capital exercise, whereas the Volksbanken did not significantly change their lending in response.

For the first diff-in-diff analysis, we define the treatment group as the Sparkassen in the treated states that were linked to HELABA or NordLB. In this analysis, the control group consists of the Sparkassen and Volksbanken in other states - i.e., states unaffected by capital exercise (the Volksbanken in the treated states are left out of this estimation). The results are reported in Table 10. Columns (I), (II), and (III) show the results for treated banks without any fixed effect, with bank fixed effects, and with both bank and time fixed effects, respectively. The coefficient of the interaction term, EBA*treated, is negative and significant at the $1 \%$ level in all the estimations. This means that treated Sparkassen reduced their lending compared to the control group after the 2011 capital exercise.

For the second diff-in-diff analysis, we investigate the effect of the EBA capital exercise on the unaffected banks in treated states. Therefore, we define the treatment group as the Volksbanken in treated states. The control group is defined as the Sparkassen and Volksbanken in other states as before. The aim is to see if the reduction of lending by banks in the treated states is due to an unobserved, coincidental common shock affecting all banks within the treated states or it is driven by reduced lending by the Sparkassen linked to HELABA and NordLB. Columns (IV), (V), and (VI) in Table 10 present the results for a diff-in-diff estimation using these banks as the "treatment group" for this exercise. The coefficient of the interaction term $\mathrm{EBA}_{t}{ }^{*}$ treated $_{b}$ is positive but not significant, including only bank fixed effects; it is significant when both time and bank fixed effects are included. This suggests that the Volksbanken in treated states may have increased their lending in response to the decline in lending by the Sparkassen, but it was not enough to arrest the decline 
in total lending in the treated states. This result is consistent with the view that unaffected banks in treated states were not able to make up for the reduction in lending by the affected banks.

[Table 10

The role of bank capital: Next, we want to explore further why the unaffected banks in treated states were not able to fill the lending vacuum created by the treated banks. Our hypothesis is that it was because they lacked sufficient capital to expand their lending. In our sample, there were nine unaffected banks in the treated states. For this examination, we focus on the capital ratios of the unaffected banks in the treated states. We compare banks' lending in 2012 to lending in the same month one year earlier. We define a dummy variable called Expansion that takes the value one if the observation belongs to the top quartile of lending increases. We then regress this dummy on bank capital. More specifically, we estimate the following regression:

$$
\text { Expansion }_{t, b}=\alpha_{0}+\alpha_{1} \text { capital }_{t, b}+\Delta_{t}+u_{t, b}
$$

The dependent variable Expansion Ex $_{t}$ is a dummy variable that takes the value one if the oneyear increase in lending volume in 2012 puts the bank in the top quartile of lending increases, and zero otherwise. $\Delta_{t}$ is the time-fixed-effect variable and $u_{t, b}$ is the error term. capital $l_{t, b}$ is the equity capital of bank $b$ at time $t$. The sample includes only banks unaffected by the capital exercise in states where HELABA and NordLB are present, and the time period is from January 2012 to December 2012. The estimation results are reported in Table 11.

[Table 11$]$

Table 11 shows that the unaffected banks in treated states that had higher capital increased their lending by a larger amount in response to the capital shock experienced by the affected banks. The coefficient is positive and significant both with and without the inclusion of time fixed effects. That is, among the banks in treated states that were unaffected by the EBA capital exercise, banks with lower capital were less able to fill the lending vacuum created by the affected banks.

In summary, we conclude that P2P lending expands more in states in which some banks experience higher regulatory costs and in which unaffected banks lack sufficient capital to replace the 
reduction of credit supply by the affected banks. This result is consistent with the predictions of our model.

Google Search analysis: Lastly, we want to understand the effect of the poaching cost, $\widetilde{\alpha}$, faced by P2P lenders in luring away bank borrowers. Our model predicts that a lower poaching cost would enable P2P lenders to take a larger market share away from banks. Since P2P lending is an online-only service, in order to access the P2P platform, users frequently search for the word "Auxmoney" using search engines like Google. Thus, we use Google search volumes as provided by Google Trends to capture consumer awareness of Auxmoney in different regions. The idea is that the larger is consumer awareness, the lower is $\widetilde{\alpha}$, and the greater is the competition Auxmoney offers to banks.

We downloaded the time series of the search-data index of the word Auxmoney for each German state from January 2007 until November 2017. The search-data index in Google Trends are normalized to 100 for the month of highest search for each state. Also, Google Trends provides the relative amount of search between the states. Thus, in order to compare across states and through time within states, we renormalize the time series of the different states according to the ranking of the relative search across states. In particular, we use the ranking value as of November 2017 as the conversion factor of the time series of the state. For example, the highest search in November 2017 is in the state of Thuringia and Google Trends assigns a value of 100 to this state. We therefore assign a conversion factor of 1 to this state. The second state is Mecklenburg-Western Pomerania with 94 , and we use a conversion factor equal to 0.94 for the time series of Mecklenburg-Western Pomerania, etc.

Figure [6]presents the average Google search for the word "Auxmoney" in Germany from January 2010 until September 2014 (the sample period considered for our analysis). This value has a clear positive trend, which is consistent with the positive lending growth of $\mathrm{P} 2 \mathrm{P}$ lending previously described.

[Figure 6]

Descriptive statistics of Google search for the word "Auxmoney" in the different states and for Germany overall are reported in Table 12.

[Table 12 
Table 12 shows that there is considerable heterogeneity across the different states in searches for the word "Auxmoney." The state with the lowest mean is Saarland (32.7) and one with the highest mean is Saxony (56.3). There is also a large variability in search through time within the different states. The state with the largest standard deviation is Brandenburg (41.5) and the one with the lowest is North Rhine-Westphalia (28.3). Because of this variability, the ranking changes intertemporally. This heterogeneity across states and within states through time enables us to use this variable to investigate whether different levels of "consumer awareness" matter for differences in the impact of Auxmoney lending on bank lending cross-sectionally and though time.

We also use the EBA capital exercise for this investigation. We define a dummy called Google Search that equals one if the state was in the top 50th percentile of Google searches between January 2010 and October 2011 (i.e., prior to the EBA capital exercise) and zero otherwise.

We use this dummy variable as an explanatory variable in the diff-in-diff estimation previously described. Table 13 reports the results. The first two columns of this tables corresponds to the regression reported in Columns (I), (IV), and (VII) of Table 9, respectively. Since the results of the diff-in-diff estimation have been already discussed, we focus on the coefficient of the dummy Google Search.

[Table 13

As Table 13 shows, the dummy Google Search is statistically significant in all estimations at the $5 \%$ level. The table shows that greater awareness of P2P lending leads to a bigger decline in new lending by banks in treated states both at the aggregated (column I) and individual bank (column II) levels, and to a bigger increase in P2P lending (column III). P2P lenders also increased lending in states in which there was more search for Auxmoney prior to the EBA stress test. This result shows that P2P lending increases more and bank lending decreases more after a capital shock in regions in which there is greater consumer awareness of Auxmoney. It is worth stressing that the other coefficients retain their previous statistical significance as in table Table 9, so "consumer awareness" of P2P lending is a complementary channel for the effect of P2P lending on bank lending. 


\subsection{Hypothesis 2: P2P loans are riskier than bank loans.}

In order to investigate whether Auxmoney loans are statistically significantly riskier than bank loans as predicted by our theoretical model, we pool all risk observations from all 105 banks and all maturities (overdraft, up to one year, and between one and five years), as well as those of Auxmoney provided in the different states, and regress them on a dummy variable that takes the value one if the observation refers to an Auxmoney loan provided, and zero otherwise:

$$
\sigma_{t, b}=\beta_{1} \text { auxmoney }_{t, b}+\Delta_{s}+\Delta_{t}+u_{t, b}
$$

where $\sigma_{t, b}$ is the probability of default of loans provided by bank $b$, auxmoney ${ }_{t, b}$ is a dummy variable that takes value one when the lender is Auxmoney and zero otherwise, $\Delta_{s}$ and $\Delta_{t}$ are state and time fixed effects, respectively, and $u_{t, b}$ is the error term.

[Table 14

Table 14 presents the estimations. It shows that the default probability of Auxmoney loans is significantly higher than the default probability of bank loans. Typically, Auxmoney borrowers have about a $7.3 \%$ higher probability of default. The result is robust to the inclusion of state and time fixed effects. This result provides support for Hypothesis 233

\subsection{Hypothesis 3: The risk-adjusted interest rates on bank loans are higher than the risk-adjusted interest rates on $\mathrm{P} 2 \mathrm{P}$ loans.}

Since P2P loans are riskier and carry higher interest rates than bank loans, we compare loan interest rates after adjusting for risk differences - i.e., we test our third hypothesis.

We calculate the risk-adjusted interest rates charged by both $\mathrm{P} 2 \mathrm{P}$ lending and banks under the assumption of risk neutrality by using the following formula:

$$
r_{t, b}=\left(1-\sigma_{t, b}\right) \times\left(1+i_{t, b}\right)+\sigma_{t, b} \times R R_{t, b}-1,
$$

\footnotetext{
${ }^{33}$ As indicated earlier, Schufa reports an average probability of default of $2.5 \%$ for German borrowers. Our ex ante default probability is marginal and is higher for reasons discussed earlier. If we adjusted the mean of the default probability risk distribution for bank loans to $2.5 \%$ the default risk of $\mathrm{P} 2 \mathrm{P}$ lending would still be higher than that for banks. Thus, even if our measurements of the default risk of banks loans was biased, Hypothesis 2 would hold.
} 
where $r_{t, b}$ is the risk-adjusted interest rate charged by bank $b$ at time $t, i_{t, b}$ is the nominal (stated) interest rate, and $\sigma_{t, b}$ is the probability of default that we have already described in Section 3 . $R R_{t, b}$ is the recovery rate. We repeat the same procedure for P2P lending 34 Table 15 reports the summary statistics of the risk-adjusted interest rates for both bank and P2P loans. An eyeballing of the data in this table indicates that, after adjusting for risk differences, Auxmoney interest rates move closer to those on bank loans. The standard deviation of the risk-adjusted interest rates on $\mathrm{P} 2 \mathrm{P}$ loans is larger than that for banks, 3.34 versus 1.43. This result is driven by the greater default-risk heterogeneity among P2P borrowers than among bank borrowers, something not evident in the earlier data presented in Table 2

[Table 15

As before, we test whether the risk-adjusted interest rates on $\mathrm{P} 2 \mathrm{P}$ and bank loans are significantly different using a dummy variable:

$$
r_{t, b}=\beta_{2} \text { auxmoney }_{t, b}+\Delta_{j}+\Delta_{t}+e_{t, b}
$$

where $r_{b, t}$ is the risk-adjusted interest rate charged by bank $b$ or Auxmoney, auxmoney ${ }_{t, t}$ is a dummy variable that takes value one when the lender is Auxmoney and zero otherwise, $\Delta_{s}$ and $\Delta_{t}$ are state and time fixed effects, respectively, and $u_{t, b}$ is the error term.

Table 16 presents the results. Consistent with our hypothesis, after adjusting loan interest rates for risk differences, we find that Auxmoney charges lower interest rates than banks on its loans. Auxmoneys risk-adjusted interest rate is between $1.87 \%$ and $2 \%$ lower than that on bank loans. The difference is statistically significant at the $1 \%$ level and is robust to including state fixed effects, time fixed effects, or both. This result provides support for our Hypothesis 3.35

[Table 16

\footnotetext{
${ }^{34}$ We assume zero recovery rate for both $\mathrm{P} 2 \mathrm{P}$ and bank lending because loans are fully written down from banks' balance sheets.

${ }^{35}$ If we adjusted the mean of the default risk distribution for bank loans to $2.5 \%$, the difference between riskadjusted interest rates would change, but the risk-adjusted interest rate for Auxmoney loans would still be lower than that for bank loans, and Hypothesis 3 would continue to be supported.
} 


\section{Conclusion}

This paper examines how P2P lenders and banks compete for borrowers. We develop a simple theoretical model of bank and P2P lending that generates predictions, and we test these predictions.

In the empirical analysis, we investigate three testable hypotheses that are the predictions of the model. First, we document that P2P lending increases and total bank lending declines when some banks face higher regulatory costs. We examine an exogenous shock to the capital requirements of some banks and provide causal evidence, through a diff-in-diff analysis, that P2P lending increases when some banks face higher regulatory costs. This effect is more pronounced in states where borrowers are more "aware" of Auxmoney's existence - i.e., where these two forms of lending are at least partial substitutes ${ }^{36}$ Second, we document that Auxmoney, the largest P2P lender in Germany, charges higher loan interest rates than banks. But we also find that P2P borrowers are riskier and less profitable than bank borrowers. This means that P2P lenders are not skimming the cream. Rather, they are bottom fishing when they pry borrowers away from banks. Third, once we control for default risk, we find that risk-adjusted interest rates are lower for $\mathrm{P} 2 \mathrm{P}$ loans than for bank loans.

One of the implications of our findings is that the advent of P2P lending may cause the banking sector to shrink, but also to be less risky and possibly more profitable in terms of risk-adjusted returns on assets. Whether this is underway on a broader scale in the credit market is an interesting topic for future research.

\section{References}

Bade, M., and R. Beier. 2016. Microdatabase: MFI Interest Rate Statistics. Deutsche Bundesbank Data Report 2016-02: Research Data and Service Centre.

Beier, R., M. Krueger, and M. Schaefer. 2016. Microdatabase: Monthly Balance Sheet Statistics. Deutsche Bundesbank Data Report 2016-01:Research Data and Service Centre.

\footnotetext{
${ }^{36}$ Our results do not rule out possible complementarity - i.e., P2P platforms provides credit to borrowers who have loans with NPVs that are negative for banks but positive for P2P lenders.
} 
Buchak, G., G. Matvos, T. Piskorski, and A. Seru. 2017. Fintech, Regulatory Arbitrage, and the Rise of Shadow Banks. National Bureau of Economic Research WP.23288.

Cerqueiro, G., S. Ongena, and K. Roszbach. 2016. Collateralization, bank loan rates, and monitoring. The Journal of Finance 71:1295-1322.

Coval, J. D., and A. V. Thakor. 2005. Financial Intermediation as a Beliefs-Bridge between Optimists and Pessimists. Journal of Financial Economics 75:535-569.

Diamond, D. W. 1984. Financial Intermediation and Delegated Monitoring. The Review of Economic Studies 51:393-414.

Diamond, D. W., and P. H. Dybvig. 1983. Bank Runs, Deposit Insurance, and Liquidity. Journal of Political Economy 91:401-419.

Donaldson, J. R., G. Piacentino, and A. Thakor. 2018. Warehouse Banking. Journal of Financial Economics, forthcoming.

Greenwood, R., and D. Scharfstein. 2013. The Growth of Finance. The Journal of Economic Perspectives 27:3-28.

Gropp, R., T. Mosk, S. Ongena, and C. Wix. 2018. Bank response to higher capital requirements: Evidence from a natural experiment. Review of Financial Studies forthcoming.

Holmstrom, B., and J. Tirole. 1997. Financial intermediation, loanable funds, and the real sector. the Quarterly Journal of Economics 112:663-691.

Korczak, D., and M. Wilken. 2010. Consumer Information Scoring. Federal Ministry for Agriculture and Consumer Protection.

Lin, M., N. R. Prabhala, and S. Viswanathan. 2013. Judging Borrowers by the Company They Keep: Friendship Networks and Information Asymmetry in Online Peer-to-Peer Lending. Management Science 59:17-35.

Memmel, C., Y. Gündüz, and P. Raupach. 2015. The Common Drivers of Default Risk. Journal of Financial Stability 16:232-247. 
Merton, R. C., and R. T. Thakor. 2018. Customers and Investors: A framework for understanding the evolution of financial institutions. Journal of Financial Intermediation, forthcoming.

Milne, A., and P. Parboteeah. 2016. The Business Models and Economics of Peer-to-Peer Lending. ECRI Research Report .

Morse, A. 2015. Peer-to-peer crowdfunding: Information and the potential for disruption in consumer lending. Annual Review of Financial Economics 7:463-482.

Philippon, T. 2015. Has the US finance industry become less efficient? On the theory and measurement of financial intermediation. The American Economic Review 105:1408-1438.

Philippon, T. 2016. The FinTech Opportunity. National Bureau of Economic Research WP. 22476.

Pope, D. G., and J. R. Sydnor. 2011. What's in a Picture? Evidence of Discrimination from Prosper.com. Journal of Human Resources 46:53-92.

PricewaterhouseCoopers. 2015. Peer Pressure: How Peer-to-Peer Lending Platforms are Transforming the Consumer Lending Industry. Technical Report.

Puri, M., J. Rocholl, and S. Steffen. 2011. Global Retail Lending in the Aftermath of the US Financial Crisis: Distinguishing between supply and demand effects. Journal of Financial Economics 100:556-578.

Puri, M., J. Rocholl, and S. Steffen. 2017. What Do a Million Observations Have to Say About Loan Defaults? Opening the Black Box of Relationships. Journal of Financial Intermediation, forthcoming.

Ramakrishnan, R. T., and A. V. Thakor. 1984. Information Reliability and a Theory of Financial Intermediation. The Review of Economic Studies 51:415-432.

Tang, H. HEC Paris 2018. Peer-to-Peer Lenders versus Banks: Substitutes or Complements? Mimeo. 


\section{Figures}

Figure 1. New Lending by P2P Platforms and Banks.

This figure shows the volume of new consumer loans per quarter of German banks and Auxmoney, the largest P2P lending platform in Germany. Bank lending refers to nonconstruction consumer credit lines (overdraft credit, lines with up to one year maturity, and lines with between one and five years maturity) in 105 Sparkassen and Volksbanken in Germany, and is defined in billions of $€$. Auxmoney's credit provision is defined in millions of $€$. Source: Research Data and Service Center (RDSC) of the Deutsche Bundesbank, MFI Interest Rates Statistics, and Auxmoney, sample period: first quarter 2010 until first quarter 2014.




Figure 2. Sequence of events of the model.This figure summarizes the timing of the model.

\begin{tabular}{c}
\hline Sequence of Events \\
$\qquad \mathrm{t}=0$ \\
\hline $\mid$
\end{tabular}

- Bank's cost of acquiring a borrower, $\hat{\alpha}$, is realized. P2P platforms face the same cost.

- Borrower takes a loan of $L$, with repayment obligation of $L_{R}^{i}$, $i \in\{g, G\}$.

- Good loan can be $g$ or $G$.

- Bank can also invest in $B$ loan that generates private benefit $\Pi$.

- $L$ is financed with a mix of debt, $D^{i}$, and equity, $E^{i}$.

- A competing bank may or may not arrive.

- $g$ pays off $L_{R}^{g}$ with probability(w.p.) $q$ and 0 w.p. $1-q$.

- $G$ pays off $L_{R}^{G}$ with probability(w.p.) $p$ and 0 w.p. $1-p$.

- $p>q$.

- All contracts are settled, and depositors are repaid $D_{R}^{G}$ if the bank experiences loan repayment. Depositors also receive $\gamma D$ if the bank does not default. 
Figure 3. Share of credit provision by Auxmoney and banks on state-by-state basis in our sample.

This figure shows the geographical distribution of bank lending and P2P lending within our sample. The bright bar represents the share of Auxmoney lending in a giving state (in \%). The dark bar represents the share of bank lending in a given state (in \%). Source: Research Data and Service Center (RDSC) of the Deutsche Bundesbank, MFI Interest Rates Statistics, and Auxmoney, sample period January 2010 until September 2014.




Figure 4. Lending by banks over time.

This figure shows the volume of new bank loans divided into two groups. Treated refers to states where HELABA and NordLB are present, control refers to all other states in the sample over the period 2010Q1-2014Q1. Source: Research Data and Service Center (RDSC) of the Deutsche Bundesbank, MFI Interest Rates Statistics, and authors' calculation.




Figure 5. Lending by Auxmoney over time.

This figure shows the volume of new Auxmoney loans divided into two groups. Treated refers to states linked to HELABA and NordLB, control refers to all other states in the sample. Source: Auxmoney, authors' calculation.

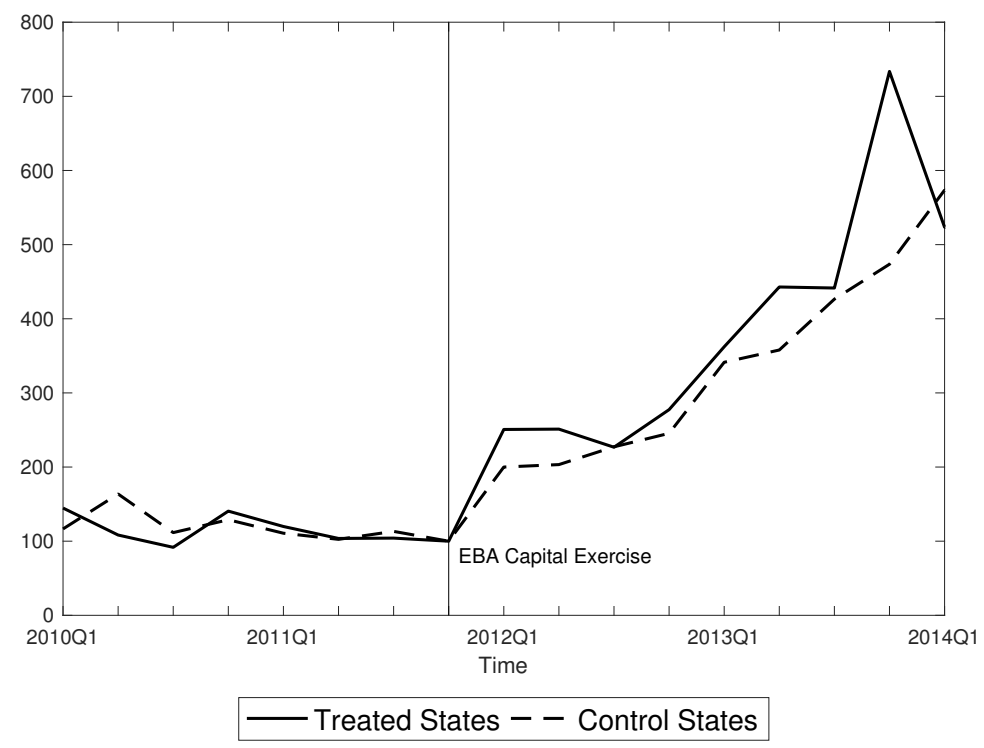

Figure 6. Google Search for "Auxmoney".

The figure shows that the interest for Auxmoney, measured by the number of searches for the word "Auxmoney", increases over time. Google search is the average search for the word Auxmoney, and values are normalized to 100 at the largest observation. Source: Google Trends.

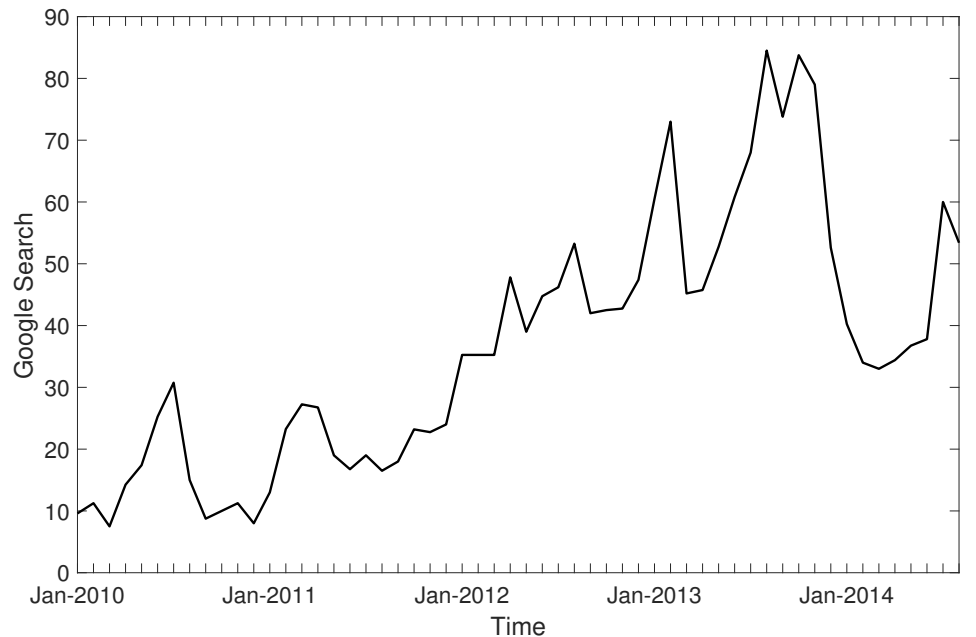




\section{Tables}

Table 1. Promised loan-repayment obligations to bank and the bank's promised deposit-repayment obligations.

This table summarizes the notation used in the model.

\begin{tabular}{|c|c|c|c|c|}
\hline \multirow{2}{*}{$\begin{array}{l}\text { Loan Type } \\
\text { Is a competing bank present? }\end{array}$} & \multicolumn{2}{|c|}{$g$} & \multicolumn{2}{|c|}{$G$} \\
\hline & No competing bank & Competing bank & No competing bank & Competing bank \\
\hline $\begin{array}{c}\text { Incumbent Bank } \\
\text { Borrower's promised repayment } \\
\text { obligation, } L_{R}^{i}\end{array}$ & $x$ & $\widehat{L}_{R}^{g}$ & $x$ & $\widehat{L}_{R}^{G}$ \\
\hline $\begin{array}{c}\text { Level of deposit, } D^{i} \\
\text { raised at } \mathrm{t}=1\end{array}$ & $\bar{D}^{g}$ & $\widehat{D}^{g}$ & $\bar{D}^{G}$ & $\widehat{D}^{G}$ \\
\hline $\begin{array}{c}\text { Repayment promised by } \\
\text { incumbent bank and its } \\
\text { depositors, } D_{R}^{i} \\
\end{array}$ & $\bar{D}_{R}^{g}$ & $\widehat{D}_{R}^{g}$ & $\bar{D}_{R}^{G}$ & $\widehat{D}_{R}^{G}$ \\
\hline Competing Bank & & & & \\
\hline $\begin{array}{c}\text { Borrower's promised repayment } \\
\text { obligation, } \widetilde{L}_{R}^{i}\end{array}$ & - & $\widetilde{L}_{R}^{g}=\widehat{L}_{R}^{g}$ & - & $\widetilde{L}_{R}^{G}=\widehat{L}_{R}^{G}$ \\
\hline $\begin{array}{l}\text { Level of deposit, } \widetilde{D}^{i} \\
\text { raised at } \mathrm{t}=1\end{array}$ & - & $\widetilde{D}^{g}$ & - & $\widetilde{D}^{G}$ \\
\hline $\begin{array}{c}\text { Repayment promised by } \\
\text { incumbent bank and its } \\
\text { depositors, } \widetilde{D}_{R}^{i}\end{array}$ & - & $\widetilde{D}_{R}^{g}$ & - & $\widetilde{D}_{R}^{G}$ \\
\hline
\end{tabular}


Table 2. Descriptive statistics of banks' and Auxmoney's interest rates, $i$, on new consumer loans.

This table shows the descriptive statistics for interest rates, $i$, charged by banks and Auxmoney on new consumer loans. Interest rates are the average interest rate charged by each single bank in each month on new consumer loans. Interest rates on bank loans are divided in three categories: overdraft, $i^{o}$; short-term loans, $i^{s}$, which have a maturity from less than one year; and midterm loans, $i^{m}$, which have a maturity between one and five years. For data protection reasons, minimum and maximum values for banks cannot be presented. Auxmoney interest rates, $i^{P 2 P}$, are the average interest rates charged by Auxmoney in each German state per month on new consumer loans. Source: Research Data and Service Center (RDSC) of the Deutsche Bundesbank, MFI Interest Rates Statistics, and Auxmoney, sample period January 2010 until September 2014.

\begin{tabular}{lccccc}
\hline \hline & \multicolumn{3}{c}{ Banks } & & Auxmoney \\
\cline { 2 - 3 } \cline { 6 - 6 } & $i^{o}$ & $i^{s}$ & $i^{m}$ & & $i^{P 2 P}$ \\
\hline Mean & 11.10 & 3.50 & 4.63 & & 12.82 \\
Std Deviation & 1.57 & 1.45 & 1.06 & & 0.90 \\
Min & - & - & - & & 10.33 \\
$25^{\text {th }} \mathrm{pcl}$ & 10.32 & 2.48 & 3.92 & & 12.21 \\
$50^{\text {th }} \mathrm{pcl}$ & 11.33 & 3.31 & 4.60 & & 12.84 \\
$75^{\text {th }} \mathrm{pcl}$ & 12.15 & 4.37 & 5.29 & \\
Max & - & - & - & \\
\# Obs & 6,598 & 6,598 & 6,512 & & 590.12 \\
\hline \hline
\end{tabular}


Table 3. Lending volume, $L$, (in $€$ ) by bank and month.

This table shows the descriptive statistics of the total volume of new consumer loans, $L$, per month by banks and for Auxmoney per German state and month. Bank loans are divided into three categories: overdraft, $L^{o}$; short-term loans, $L^{s}$, which have a maturity from less than one year; and midterm loans, $L^{m}$, which have a maturity between one and five years. For data protection reasons, minimum and maximum values for banks cannot be presented. New Auxmoney loan volume, $L^{P 2 P}$, is the total volume of new consumer loans provided by Auxmoney in each German state per month.This table shows that the mean size of Auxmoney is smaller than the mean size of any of the three bank loan categories. Source: Research Data and Service Center (RDSC) of the Deutsche Bundesbank, MFI Interest Rates Statistics, and Auxmoney, sample period January 2010 until September 2014.

\begin{tabular}{|c|c|c|c|c|}
\hline & \multicolumn{3}{|c|}{ Banks } & \multirow{2}{*}{$\frac{\text { Auxmoney }}{L^{P 2 P}}$} \\
\hline & $L^{o}$ & $L^{s}$ & $L^{m}$ & \\
\hline Mean & $77,858,060$ & $9,421,488$ & $3,233,024$ & 252,089 \\
\hline Std. Deviation & $62,868,420$ & $26,076,650$ & $2,804,759$ & 292,034 \\
\hline $25^{t h} \mathrm{pcl}$ & $38,877,000$ & $1,210,000$ & $1,464,000$ & 85,503 \\
\hline $50^{t h} \mathrm{pcl}$ & $61,509,000$ & $3,110,000$ & $2,649,000$ & 160,022 \\
\hline $75^{t h} \mathrm{pcl}$ & $94,848,000$ & $7,748,000$ & $4,098,500$ & 297,367 \\
\hline \# Obs & 6,598 & 6,598 & 6,512 & 590 \\
\hline
\end{tabular}


Table 4. Distribution of Auxmoney loans by maturity.

This table shows the distribution of Auxmoney loans by maturities in terms of number of loans (\# Loans) and total volume (Volume). Auxmoney loan maturities range from one to five years and are divided into five buckets. Source: Auxmoney, sample period October 2008 until September 2014. Note: This statistic was provided separately by Auxmoney.

\begin{tabular}{lcc}
\hline \hline & \multicolumn{2}{c}{ Auxmoney } \\
\cline { 2 - 3 } Maturity & \# Loans & Volume \\
\hline 12 & 1,310 & $3,688,350$ \\
24 & 2,533 & $9,221,550$ \\
36 & 3,292 & $15,813,900$ \\
48 & 2,084 & $16,356,700$ \\
60 & 1,405 & $16,140,600$ \\
\hline \hline
\end{tabular}


Table 5. Schufa score and default probabilities.

Schufa scores for different credit qualities and equivalent default probability measures. The higher the score, the lower the default probability. Source: Korczak and Wilken (2010).

\begin{tabular}{lccc}
\hline Rating & Score & \% of the pop. & Default prob. \\
\hline A & & & \\
B & $572-1000$ & ca $20 \%$ & $0.88 \%$ \\
C & $569-671$ & ca $20 \%$ & $1.85 \%$ \\
D & $466-568$ & ca $10 \%$ & $2.72 \%$ \\
E & $406-465$ & ca $10 \%$ & $3.69 \%$ \\
F & $336-405$ & ca $10 \%$ & $4.81 \%$ \\
G & $243-335$ & ca $10 \%$ & $6.25 \%$ \\
H & $175-242$ & ca $5 \%$ & $12.95 \%$ \\
I & $137-174$ & ca $2 \%$ & $16.64 \%$ \\
K & $112-136$ & ca $1 \%$ & $19.78 \%$ \\
L & $79-111$ & ca $1 \%$ & $24.27 \%$ \\
M & $0-78$ & ca $1 \%$ & $37.83 \%$ \\
\hline \hline
\end{tabular}


Table 6. Descriptive statistics of the default probability, $\sigma$, (in \%).

This table shows the default probabilities, $\sigma$, of new bank loans and new Auxmoney, $P 2 P$, loans. Default probabilities of new bank loans are divided into three categories: overdraft, $\sigma^{o}$; short-term loans, $\sigma^{s}$, which have maturities below one year; and midterm loans, $\sigma^{m}$, which have maturities between one and five years. The default probabilities of Auxmoney loans, $\sigma^{P 2 P}$, are derived from Schufa scores and those of banks are derived from loan write-downs. The Schufa score transformation table is reported in the Appendix. For data protection reasons, minimum and maximum values for banks cannot be presented. Source: Research Data and Service Center (RDSC) of the Deutsche Bundesbank, MFI Interest Rates Statistics and Monthly Balance Sheet Statistics, and Auxmoney, sample period January 2010 until September 2014.

\begin{tabular}{|c|c|c|c|c|}
\hline & \multicolumn{3}{|c|}{ Banks } & \multirow{2}{*}{$\frac{\text { Auxmoney }}{\sigma^{P 2 P}}$} \\
\hline & $\sigma^{o}$ & $\sigma^{s}$ & $\sigma^{m}$ & \\
\hline Mean & 0.10 & 0.14 & 0.03 & 7.32 \\
\hline Std Deviation & 0.36 & 0.59 & 0.24 & 2.91 \\
\hline Min & - & - & - & 0.88 \\
\hline $25^{t h} \mathrm{pcl}$ & 0.00 & 0.00 & 0.00 & 6.25 \\
\hline $50^{t h} \mathrm{pcl}$ & 0.05 & 0.09 & 0.01 & 6.25 \\
\hline $75^{t h} \mathrm{pcl}$ & 0.17 & 0.24 & 0.06 & 8.77 \\
\hline Max & - & - & - & 24.27 \\
\hline \# Obs & 5,800 & 5,800 & 5,886 & 590 \\
\hline
\end{tabular}


Table 7. Relation between bank lending volume and Auxmoney lending volume.

This table shows the relation between bank and Auxmoney volumes of new consumer loans per month and per state. We estimate: $\log \left(L_{b_{j} t}^{b a n k}\right)=\gamma_{1} \log \left(L_{j t}^{P 2 P}\right)+\gamma_{2} \log \left(L_{-b_{j} t}^{b a n k}\right)+\Delta_{s}+\Delta_{t}+\epsilon_{b_{s}}$, where $L_{b_{s} t}$ is the lending volume of bank $b$ in state $s$ at time $t ; L_{-b_{s} t}$ is the lending volume by all other banks, $-b$, in state $s$ at time $t$; and $L_{s t}^{P 2 P}$ is the lending volume from Auxmoney in state $s$ and at time $t, \Delta_{s}$ is the state fixed effect, and $\Delta_{t}$ is the time fixed effect. ${ }^{* * *},{ }^{* *}$, and ${ }^{*}$ represent significance at the 1\%,5\%, and 10\% levels, respectively. Source: Research Data and Service Center (RDSC) of the Deutsche Bundesbank, MFI Interest Rates Statistics, sample period January 2010 until September 2014.

\begin{tabular}{lccc}
\hline \hline & & & \\
& $(\mathrm{I})$ & $(\mathrm{II})$ & $(\mathrm{III})$ \\
& $\log \left(L_{b_{s} t}\right)$ & $\log \left(L_{b_{s} t}\right)$ & $\log \left(L_{b_{s}}\right)$ \\
\hline & & & \\
$\log \left(L_{s t}^{P 2 P}\right)$ & 0.01 & $-0.15^{* * *}$ & $-0.02^{* *}$ \\
& $(0.03)$ & $(0.03)$ & $(0.01)$ \\
& & & \\
$\log \left(\mathrm{L}_{-b_{s}}\right)$ & -0.09 & $-1.30^{* * *}$ & $-1.41^{* * *}$ \\
& $(0.14)$ & $(0.24)$ & $(0.34)$ \\
& & & \\
State FE & & Yes & Yes \\
Time FE & & & Yes \\
Cluster & Bank & Bank & Bank \\
adj. R $\mathrm{R}^{2}$ & 0.01 & 0.32 & 0.35 \\
$\#$ Obs & 6,026 & 6,026 & 6,026 \\
\hline \hline
\end{tabular}


Table 8. Pre-treatment characteristics of banks and Auxmoney.

This table shows the lending volume, interest rates, and default probability for loans made by banks and Auxmoney in treated states and control states in the pre-treatment period (November 2010 until September 2011). Panel A provides average statistics for new bank loan volume aggregated by state, Panel B describes the data for individual banks' new loan volume, and Panel C describes the data for Auxmoney. We perform a test for differences in means using the Students t-test. (*, **, and $* * *$ indicate statistical significance at the $10 \%, 5 \%$, and $1 \%$ levels, respectively). $\sigma_{t, s(b)}$ is risk in terms of default probability. Subscripts $t$ represent time, $s$ state, and $b$ bank. Source: Research Data and Service Center (RDSC) of the Deutsche Bundesbank, MFI Interest Rates Statistics and Monthly Balance Sheet Statistics, and Auxmoney.

\begin{tabular}{|c|c|c|c|}
\hline Panel A: Banks & Treated States & Control States & $\Delta$ \\
\hline log(Lending Volume) & 13.87 & 12.87 & $1.00^{* *}$ \\
\hline Interest Rate (\%) & 10.59 & 10.02 & $0.57^{* *}$ \\
\hline$\sigma_{t, s}(\%)$ & 0.11 & 0.11 & -0.00 \\
\hline Panel B: Banks & Treated Banks & Control Banks & $\Delta$ \\
\hline log(Lending Volume) & 11.02 & 11.17 & -0.15 \\
\hline Interest Rate (\%) & 11.02 & 10.09 & $0.93^{* * *}$ \\
\hline$\sigma_{t, b}(\%)$ & 0.13 & 0.09 & 0.04 \\
\hline Panel C: Auxmoney & Treated States & Control States & $\Delta$ \\
\hline $\log$ (Lending Volume) & 10.57 & 10.77 & -0.19 \\
\hline Interest Rate (\%) & 13.84 & 13.69 & $0.15^{* *}$ \\
\hline$\sigma_{t, s}(\%)$ & 7.51 & 8.18 & $-0.67^{*}$ \\
\hline
\end{tabular}


Table 9. Difference-in-differences estimation to determine effect of capital exercise on aggregate bank lending and P2P lending in treated states.

This table shows that overall bank lending declines and P2P lending increases in treated states. The table reports the estimated coefficient of the following three regressions: (i) State bank lending: $\log \left(L_{t, s}\right)=\alpha_{1}$ treated $_{s} * E B A_{t}+\alpha_{2} E B A_{t}+\alpha_{3}$ treated $_{s}+\Pi W_{t, s}+u_{t, s}$, (ii) Individual bank lending: $\log \left(L_{t, b}\right)=\alpha_{1}$ treated $_{b} * E B A_{t}+\alpha_{2} E B A_{t}+\alpha_{3}$ treated $_{b}+\Pi W_{t, b}+u_{t, b}$, and (iii) P2P lending: $\log \left(L_{t, s}\right)=\beta_{1}$ treated $_{s} * E B A_{t}+\beta_{2} E B A_{t}+\beta_{3}$ treated $_{s}+\Pi W_{t, s}+e_{t, s}$. Estimation (ii) is in the individual bank dimension and estimations (i) and (iii) are in the state dimension. The dependent variable $L_{t, b}$ is the total lending volume by bank $b$ in month $t$, the dependent variable $L_{t, s}$ is the total lending volume in state $s$ in month $t, E B A_{t}$ is the treatment dummy that takes the value one from October 2011 onwards and zero prior to that, and $\operatorname{treated}_{t, s(b)}$ is the dummy variable that identifies banks in the treated states and is equal to one for treated states (i.e., where HELABA or NordLB were present) and zero otherwise. In estimation (i), a treated state is one where HELABA and NordLB were present and the dependent variable is the total bank lending in that state. The control is total bank lending in other states (where HELABA or NordLB were not present). In estimation (ii), all banks (i.e., both Sparkassen and Volksbanken) in treated states are considered treated banks and those in control states are control banks. The dependent variable is the lending by an individual bank in the treated state. $W_{t, s(b)}$ is a vector of control variables that includes the default probability, $\sigma$ - i.e., our proxy for risk - and interest rate is the average interest rate for new loans. Notation s(b) means that variable is in state dimension (I-III, VII-IX), and in the individual bank dimension in estimations (IV-VI). ${ }^{* * *},{ }^{* *}$, and ${ }^{*}$ represent significance at the 1\%, 5\% and 10\% levels, respectively. Source: Research Data and Service Center (RDSC) of the Deutsche Bundesbank, MFI Interest Rates Statistics and Monthly Balance Sheet Statistics, and Auxmoney.

\begin{tabular}{|c|c|c|c|c|c|c|c|c|c|}
\hline & \multicolumn{3}{|c|}{ State Bank Lending } & \multicolumn{3}{|c|}{ Individual Bank Lending } & \multicolumn{3}{|c|}{ P2P Lending } \\
\hline & $\begin{array}{c}(\mathrm{I}) \\
\log \left(L_{t, s}\right)\end{array}$ & $\begin{array}{c}(\mathrm{II}) \\
\log \left(L_{t, s}\right)\end{array}$ & $\begin{array}{c}(\mathrm{III}) \\
\log \left(L_{t, s}\right)\end{array}$ & $\begin{array}{c}(\mathrm{IV}) \\
\log \left(L_{t, b}\right)\end{array}$ & $\begin{array}{c}(\mathrm{V}) \\
\log \left(L_{t, b}\right)\end{array}$ & $\begin{array}{c}(\mathrm{VI}) \\
\log \left(L_{t, b}\right)\end{array}$ & $\begin{array}{c}(\mathrm{VII}) \\
\log \left(L_{t, s}\right)\end{array}$ & $\begin{array}{c}(\mathrm{VIII}) \\
\log \left(L_{t, s}\right)\end{array}$ & $\begin{array}{c}(\mathrm{IX}) \\
\log \left(L_{t, s}\right)\end{array}$ \\
\hline $\mathrm{EBA}_{t} *$ treated $_{t, s(b)}$ & $\begin{array}{l}-0.01 \\
(0.10)\end{array}$ & $\begin{array}{c}-0.06^{* * *} \\
(0.02)\end{array}$ & $\begin{array}{c}-0.05^{* * *} \\
(0.01)\end{array}$ & $\begin{array}{c}-0.06^{* * *} \\
(0.02)\end{array}$ & $\begin{array}{c}-0.07^{* * *} \\
(0.02)\end{array}$ & $\begin{array}{c}-0.05^{* *} \\
(0.02)\end{array}$ & $\begin{array}{c}0.60^{* * *} \\
(0.10)\end{array}$ & $\begin{array}{c}0.20^{* * *} \\
(0.08)\end{array}$ & $\begin{array}{c}0.22^{* * *} \\
(0.06)\end{array}$ \\
\hline $\mathrm{EBA}_{t}$ & $\begin{array}{c}-0.28^{* *} \\
(0.11)\end{array}$ & $\begin{array}{c}-0.12^{* * *} \\
(0.01)\end{array}$ & & $\begin{array}{c}-0.12^{* * *} \\
(0.02)\end{array}$ & $\begin{array}{c}-0.12^{* * *} \\
(0.02)\end{array}$ & & $\begin{array}{l}-0.20 \\
(0.17)\end{array}$ & $\begin{array}{c}0.60 * * * \\
(0.05)\end{array}$ & \\
\hline Treated $_{t, s(b)}$ & $\begin{array}{c}1.16^{* * *} \\
(0.08)\end{array}$ & & & $\begin{array}{l}-0.04 \\
(0.15)\end{array}$ & & & $\begin{array}{c}-0.29 * * * \\
(0.09)\end{array}$ & & \\
\hline$\sigma_{t, s(b)}$ & $\begin{array}{c}-1.06^{* *} \\
(0.50)\end{array}$ & $\begin{array}{c}0.08^{* * *} \\
(0.03)\end{array}$ & $\begin{array}{c}0.01 \\
(0.02)\end{array}$ & $\begin{array}{l}-0.02 \\
(0.02)\end{array}$ & $\begin{array}{l}-0.02 \\
(0.02)\end{array}$ & $\begin{array}{c}-0.02^{*} \\
(0.01)\end{array}$ & $\begin{array}{c}-0.03^{* * *} \\
(0.01)\end{array}$ & $\begin{array}{c}-0.02^{* *} \\
(0.01)\end{array}$ & $\begin{array}{c}-0.02^{* *} \\
(0.01)\end{array}$ \\
\hline Int. Rate $_{t, s(b)}$ & $\begin{array}{c}-0.30^{* * * *} \\
(0.08)\end{array}$ & $\begin{array}{l}-0.00 \\
(0.01)\end{array}$ & $\begin{array}{c}-0.04^{*} \\
(0.02)\end{array}$ & $\begin{array}{c}-0.02^{* * *} \\
(0.00)\end{array}$ & $\begin{array}{c}-0.02^{* * *} \\
(0.00)\end{array}$ & $\begin{array}{c}-0.06^{* * *} \\
(0.01)\end{array}$ & $\begin{array}{c}-0.10^{* * *} \\
(0.03)\end{array}$ & $\begin{array}{c}-0.17^{* * *} \\
(0.04)\end{array}$ & $\begin{array}{c}0.04 \\
(0.03)\end{array}$ \\
\hline State FE & & Yes & Yes & & Yes & Yes & & Yes & Yes \\
\hline Time FE & & & Yes & & & Yes & & & Yes \\
\hline Cluster & State & State & State & Bank & Bank & Bank & State & State & State \\
\hline adj. $R^{2}$ & 0.150 & 0.994 & 0.997 & 0.038 & 0.961 & 0.970 & 0.09 & 0.63 & 0.79 \\
\hline \# Obs & 741 & 741 & 741 & 5,754 & 5,754 & 5,754 & 590 & 590 & 590 \\
\hline
\end{tabular}


Table 10. Difference-in-differences estimation to examine the effect of the capital exercise on lending by treated and control banks in treated states.

The table reports the estimated coefficient of the following regression: $L_{b t}=\alpha_{1}$ treated $_{b} * E B A_{t}+$ $\alpha_{2} E B A_{t}+\alpha_{3}$ treated $_{b}+\Pi W_{b t}+u_{b t}$, where the dependent variable $L_{b t}$ is the lending volume by banks, $E B A_{t}$ is the treatment time dummy that takes the value one from October 2011 onwards, and treated $_{b}$ is the dummy variable that identifies the treated banks and is equal to one for treated banks and zero otherwise. In columns (I) to (III), the treatment group is the set of Sparkassen linked to treated Landesbank (HELABA or NordLB) and called affected banks. In columns (IV) to (VI), the treatment group is the set of Volksbanken in the states where HELABA or NordLB are present, called unaffected banks in treated states. For all the regressions, the control group consists of all individual banks (Sparkassen and Volksbanken) located in the states where HELABA or NordLB were not active - i.e., states that were not treated. $W_{b t}$ is a vector of control variables that includes the default probability - i.e., our proxy for risk, and the variable Int. Rate is the average nominal interest rate of new loans by bank $b$ at time $t .{ }^{* * *},{ }^{* *}$, and ${ }^{*}$ represent significance at the 1\%, 5\%, and 10\% levels, respectively. Source: Research Data and Service Center (RDSC) of the Deutsche Bundesbank, MFI Interest Rates Statistics and Monthly Balance Sheet Statistics, and Auxmoney.

\begin{tabular}{|c|c|c|c|c|c|c|}
\hline & \multicolumn{3}{|c|}{ Affected Banks (Sparkassen) } & \multicolumn{3}{|c|}{ Unaffected Banks (Volksbanken) } \\
\hline & $\begin{array}{c}(\mathrm{I}) \\
\log \left(L^{b}\right)\end{array}$ & $\begin{array}{c}(\mathrm{II}) \\
\log \left(L^{b}\right)\end{array}$ & $\begin{array}{c}\text { (III) } \\
\log \left(L^{b}\right)\end{array}$ & $\begin{array}{c}(\mathrm{IV}) \\
\log \left(L^{b}\right)\end{array}$ & $\begin{array}{c}(\mathrm{V}) \\
\log \left(L^{b}\right)\end{array}$ & $\begin{array}{c}(\mathrm{VI}) \\
\log \left(L^{b}\right)\end{array}$ \\
\hline $\mathrm{EBA}_{t} *$ Treated $_{b}$ & $\begin{array}{c}-0.09^{* * *} \\
(0.03)\end{array}$ & $\begin{array}{c}-0.07^{* * *} \\
(0.02)\end{array}$ & $\begin{array}{c}-0.07^{* * *} \\
(0.03)\end{array}$ & $\begin{array}{c}0.16 \\
(0.10)\end{array}$ & $\begin{array}{c}0.15 \\
(0.09)\end{array}$ & $\begin{array}{l}0.17^{*} \\
(0.10)\end{array}$ \\
\hline $\mathrm{EBA}_{t}$ & $\begin{array}{l}-0.01 \\
(0.13)\end{array}$ & $\begin{array}{c}-0.11^{* * *} \\
(0.02)\end{array}$ & & $\begin{array}{c}-0.16^{* * *} \\
(0.03)\end{array}$ & $\begin{array}{c}-0.14^{* * *} \\
(0.02)\end{array}$ & \\
\hline Treated $_{b}$ & $\begin{array}{c}-0.13^{* * *} \\
(0.04)\end{array}$ & & & $\begin{array}{l}-0.25 \\
(0.26)\end{array}$ & & \\
\hline$\sigma_{t, b}$ & $\begin{array}{c}0.01 \\
(0.09)\end{array}$ & $\begin{array}{l}-0.02 \\
(0.01)\end{array}$ & $\begin{array}{c}-0.02^{*} \\
(0.01)\end{array}$ & $\begin{array}{l}-0.01 \\
(0.09)\end{array}$ & $\begin{array}{l}-0.01 \\
(0.01)\end{array}$ & $\begin{array}{l}-0.02 \\
(0.01)\end{array}$ \\
\hline Int. Rate $_{t, b}$ & $\begin{array}{c}-0.08^{*} \\
(0.04)\end{array}$ & $\begin{array}{c}-0.03^{* * *} \\
(0.01)\end{array}$ & $\begin{array}{c}-0.06^{* * *} \\
(0.02)\end{array}$ & $\begin{array}{c}-0.07^{*} \\
(0.05)\end{array}$ & $\begin{array}{c}-0.03^{* * *} \\
(0.01)\end{array}$ & $\begin{array}{c}-0.07^{* * *} \\
(0.02)\end{array}$ \\
\hline $\begin{array}{l}\text { Bank FE } \\
\text { Time FE }\end{array}$ & & Yes & $\begin{array}{l}\text { Yes } \\
\text { Yes }\end{array}$ & & Yes & $\begin{array}{l}\text { Yes } \\
\text { Yes }\end{array}$ \\
\hline Cluster & Bank & Bank & Bank & Bank & Bank & Bank \\
\hline adj. $R^{2}$ & 0.039 & 0.962 & 0.971 & 0.041 & 0.962 & 0.974 \\
\hline \# Obs & 5,754 & 5,754 & 5,754 & 5,754 & 5,754 & 5,754 \\
\hline
\end{tabular}


Table 11. Test of lending responses to the shock by unaffected banks in treated states. The table reports the test of whether, among banks unaffected by the EBA capital exercise, the banks with more capital increased their lending more. The test involves the following regression: Expansion $_{t, b}=\alpha_{0}+\alpha_{1}$ capital $_{t, b}+$ Delta $_{t}+u_{t, b}$. The dependent variable Expansion Ext $_{\text {is a dummy }}$ variable that takes the value one if the one-year increase in lending volume in 2012 puts the bank in the top quartile of lending increases, and zero otherwise. The explanatory variable is the bank equity capital of bank $b$ at time $t$. The sample includes only banks unaffected by the capital exercise in states where HELABA and NordLB are present, and the time frame is from January 2012 to December 2012 . ${ }^{* * *},{ }^{* *}$, and $*$ represent significance at the $1 \%, 5 \%$ and $10 \%$ levels, respectively. Source: Research Data and Service Center (RDSC) of the Deutsche Bundesbank, Monthly Balance Sheet Statistics, and Auxmoney.

\begin{tabular}{lcc}
\hline \hline & $(\mathrm{I})$ & $(\mathrm{II})$ \\
& Expansion & Expansion \\
\hline Capital & $15.22^{* *}$ & $15.37^{* * *}$ \\
& $(6.11)$ & $(3.07)$ \\
Time FE & & Yes \\
Cluster & Bank & Bank \\
$\mathrm{R}^{2}$ & 0.132 & 0.145 \\
$\#$ Obs & 108 & 108 \\
\hline \hline
\end{tabular}


Table 12. Descriptive statistics for Google searches of the word "Auxmoney."

This table shows that descriptive statistics of Google searches of the word "Auxmoney" across states and time. We renormalize the time series of the different states provided by Google Trends according to the ranking of the relative search across states. In particular, we use the ranking value as the conversion factor of the time series of the state. Source: Google Trends.

\begin{tabular}{|c|c|c|c|c|c|c|}
\hline & Mean & $\mathrm{SD}$ & $25 \mathrm{pcl}$ & $50 \mathrm{pcl}$ & $75 \mathrm{pcl}$ & \#Obs \\
\hline \multicolumn{7}{|l|}{ Google Search "Auxmoney" } \\
\hline All States & 47.4 & 34.9 & 21.3 & 44.2 & 65.6 & 977 \\
\hline Baden-Württemberg & 52.8 & 31.9 & 28.7 & 51.6 & 69.6 & 64 \\
\hline Bavaria & 49.5 & 33.4 & 28.7 & 40.9 & 64.7 & 64 \\
\hline Berlin & 54.4 & 37.3 & 22.9 & 50.8 & 71.3 & 64 \\
\hline Brandenburg & 52.1 & 41.5 & 19.6 & 47.54 & 75.4 & 64 \\
\hline Bremen & 36.7 & 31.1 & 14.7 & 31.1 & 55.7 & 46 \\
\hline Hamburg & 42.3 & 33.3 & 19.7 & 31.1 & 55.7 & 62 \\
\hline Hesse & 48.3 & 33.1 & 18.8 & 46.7 & 63.1 & 64 \\
\hline Lower Saxony & 52.0 & 32.4 & 27.8 & 50.8 & 67.2 & 64 \\
\hline Mecklenburg-Western Pomerania & 37.9 & 39.5 & 0 & 27.8 & 67.2 & 59 \\
\hline North Rhine-Westphalia & 47.9 & 28.3 & 23.7 & 45.1 & 61.5 & 64 \\
\hline Rhineland-Palatinate & 45.6 & 32.6 & 26.2 & 36.8 & 61.5 & 64 \\
\hline Saarland & 32.7 & 30.0 & 0 & 24.6 & 55.7 & 58 \\
\hline Saxony & 56.3 & 37.3 & 27.8 & 55.7 & 72.1 & 63 \\
\hline Saxony-Anhalt & 37.3 & 30.4 & 14.7 & 36.1 & 55.7 & 58 \\
\hline Schleswig-Holstein & 54.7 & 35.3 & 32.8 & 50.8 & 75.4 & 63 \\
\hline Thuringia & 53.4 & 40.4 & 22.9 & 52.4 & 77.0 & 58 \\
\hline
\end{tabular}


Table 13. Difference-in-differences estimation and Google search for Auxmoney.

This table shows that the relationship between bank lending and P2P lending grows with consumer awareness about Auxmoney prior to the capital exercise. In column (I), the treatment group comprises the states affected by the EBA capital exercise; in column (II), the treatment group comprises the banks in treated states; and in column (III), the treatment group is Auxmoney lending in treated states. $E B A_{t}$ is the treatment dummy that takes the value one from October 2011 onwards and zero prior to that; and treated $_{t, s(b)}$ is the dummy variable that identifies banks in the treated states and is equal to one for treated states - i.e., where HELABA or NordLB were present - and equals zero otherwise, in estimation (II). Control group is defined as lending volume in states where HELABA or NordLB were not active. $\sigma$ is our proxy for risk, and interest rate is the average interest rate for new loans. Notation $\mathrm{s}(\mathrm{b})$ means that variable is in the bank dimension in estimations (I) and (III), and in the state dimension in estimations (II). ${ }^{* *},{ }^{* *}$, and ${ }^{*}$ represent significance at the $1 \%, 5 \%$, and $10 \%$ levels, respectively. Source: Research Data and Service Center (RDSC) of the Deutsche Bundesbank, MFI Interest Rates Statistics and Monthly Balance Sheet Statistics, Auxmoney.

\begin{tabular}{|c|c|c|c|}
\hline & $\begin{array}{c}\text { Aggregate Bank Lending } \\
(\mathrm{I}) \\
\log \left(L_{t, s}\right)\end{array}$ & $\begin{array}{c}\text { Overall Bank Lending } \\
\text { (II) } \\
\log \left(L_{t, b}\right)\end{array}$ & $\begin{array}{c}\text { P2P Lending } \\
\text { (III) } \\
\log \left(L_{t, s}\right)\end{array}$ \\
\hline EBA $_{t} *$ Treated $_{b}$ & $\begin{array}{c}0.00 \\
(0.10)\end{array}$ & $\begin{array}{c}-0.06^{*} \\
(0.03)\end{array}$ & $\begin{array}{c}0.35^{* * *} \\
(0.10)\end{array}$ \\
\hline $\mathrm{EBA}_{t}$ & $\begin{array}{c}-0.27^{* *} \\
(0.11)\end{array}$ & $\begin{array}{c}-0.16^{* * *} \\
(0.04)\end{array}$ & $\begin{array}{c}0.46^{* * *} \\
(0.07)\end{array}$ \\
\hline Treated $_{b}$ & $\begin{array}{c}1.11^{* * *} \\
(0.09)\end{array}$ & $\begin{array}{l}-0.18 \\
(0.17)\end{array}$ & $\begin{array}{c}0.62^{* * *} \\
(0.15)\end{array}$ \\
\hline$\sigma_{t, s(b)}$ & $\begin{array}{c}-1.16^{* *} \\
(0.54)\end{array}$ & $\begin{array}{l}-0.00 \\
(0.08)\end{array}$ & $\begin{array}{c}-0.01^{* *} \\
(0.00)\end{array}$ \\
\hline Int. Rate $s t$ & $\begin{array}{c}-0.29 * * * \\
(0.08)\end{array}$ & $\begin{array}{c}-0.11^{* *} \\
(0.04)\end{array}$ & $\begin{array}{c}-0.17^{* * *} \\
(0.04)\end{array}$ \\
\hline Google Search & $\begin{array}{c}-0.25^{* * *} \\
(0.08)\end{array}$ & $\begin{array}{c}-0.35^{* *} \\
(0.14)\end{array}$ & $\begin{array}{c}1.15^{* * *} \\
(0.25)\end{array}$ \\
\hline $\begin{array}{l}\text { Cluster } \\
\text { adj. } \mathrm{R}^{2} \\
\text { \# Obs }\end{array}$ & $\begin{array}{l}\text { State } \\
0.155 \\
741\end{array}$ & $\begin{array}{l}\text { Bank } \\
0.094 \\
5,754\end{array}$ & $\begin{array}{l}\text { State } \\
0.431 \\
590\end{array}$ \\
\hline
\end{tabular}


Table 14. Difference in the default probability of bank loans and Auxmoney loans.

This table reports the estimation of the following regression: $\sigma_{t, b}=\beta_{1}$ auxmoney $_{t, b}+\Delta_{s}+\Delta_{t}+u_{t, b}$, where $\sigma_{t, b}$ is the default probability of bank $b$ or Auxmoney, auxmoney ${ }_{b t}$ is a dummy variable equal to one when the lender is Auxmoney, and $\Delta_{s}+\Delta_{t}$ are respectively state and time fixed effects. The default probability of Auxmoney clients is derived from Schufa scores and those of banks' clients are from loan write-downs. ***,**, and * represent significance at the $1 \%, 5 \%$ and $10 \%$ levels, respectively. Source: Research Data and Service Center (RDSC) of the Deutsche Bundesbank, MFI Interest Rates Statistics and Monthly Balance Sheet Statistics, and Auxmoney, sample period January 2010 until September 2014.

\begin{tabular}{lccc}
\hline \hline & $(\mathrm{I})$ & $(\mathrm{II})$ & $(\mathrm{III})$ \\
& $\sigma_{t, b}$ & $\sigma_{t, b}$ & $\sigma_{t, b}$ \\
\hline Auxmoney Dummy & $7.33^{* * *}$ & $7.44^{* * *}$ & $7.36^{* * *}$ \\
& $(0.01)$ & $(0.04)$ & $(0.04)$ \\
State FE & & Yes & Yes \\
Time FE & & & Yes \\
Cluster & Bank & Bank & Bank \\
adj. R ${ }^{2}$ & 0.81 & 0.82 & 0.83 \\
$\#$ Obs & 5,903 & 5,903 & 5,903 \\
\hline \hline
\end{tabular}


Table 15. Summary statistics: Risk-adjusted interest rates for bank loans and P2P (Auxmoney) loans.

This table shows that after adjusting for risk difference, Auxmoney interest rates are in line with those of banks. Bank risk-adjusted interest rates are divided into three categories: overdraft, $o$; short-term loans, $s$, which have maturities less than one year; and midterm loans, $m$, which have maturities between one and five years. Source: Research Data and Service Center (RDSC) of the Deutsche Bundesbank, MFI Interest Rates Statistics and Monthly Balance Sheet Statistics, and Auxmoney, sample period January 2010 until September 2014.

\begin{tabular}{lccccc}
\hline \hline & \multicolumn{3}{c}{ Banks } & & Auxmoney \\
\cline { 2 - 3 } \cline { 6 - 6 } \cline { 5 - 6 } Mean & $r^{o}$ & $r^{s}$ & $r^{m}$ & & $r^{P 2 P}$ \\
\hline Std Deviation & 11.03 & 3.34 & 4.43 & & 4.56 \\
Min & - & - & - & & -14.55 \\
$25^{\text {th }}$ pcl & 10.24 & 2.37 & 3.80 & & 3.09 \\
$50^{\text {th }} \mathrm{pcl}$ & 11.18 & 3.17 & 4.50 & & 5.15 \\
$75^{\text {th }} \mathrm{pcl}$ & 12.01 & 4.15 & 5.20 & & 6.54 \\
Max & - & - & - & & 12.61 \\
\# Obs & 5,800 & 5,800 & 5,800 & & 590 \\
\hline \hline
\end{tabular}


Table 16. Test of difference in risk-adjusted interest rates on bank loans and Auxmoney loans.

This table reports the estimation of the following regression: $r_{t, b}=\beta_{1}$ auxmoney $_{t, b}+\Delta_{s}+\Delta_{t}+u_{t, b}$, where $r_{t, b}$ is the risk-adjusted interest rate of bank $b$ or Auxmoney, auxmoney ${ }_{t, b}$ is a dummy variable equal to 1 when the lender is Auxmoney, and $\Delta_{s}+\Delta_{t}$ are state and time fixed effects, respectively. $* * *, * *$, and $*$ represent significance at the $1 \%, 5 \%$ and $10 \%$ levels, respectively. Source: Research Data and Service Center (RDSC) of the Deutsche Bundesbank, MFI Interest Rates Statistics and Monthly Balance Sheet Statistics, and Auxmoney, sample period January 2010 until September 2014.

\begin{tabular}{lccc}
\hline \hline & $(\mathrm{I})$ & $(\mathrm{II})$ & $(\mathrm{III})$ \\
& $r$ & $r$ & $r$ \\
\hline & & & \\
Auxmoney Dummy & $-1.87^{* * * *}$ & $-2.00^{* * *}$ & $-1.91^{* * *}$ \\
& $(0.07)$ & $(0.09)$ & $(0.09)$ \\
State FE & & Yes & Yes \\
Time FE & & & Yes \\
Cluster & Bank & Bank & Bank \\
adj. R ${ }^{2}$ & 0.02 & 0.03 & 0.05 \\
$\#$ Obs & 5,885 & 5,885 & 5,885 \\
\hline \hline
\end{tabular}




\section{Appendix}

Proof of Proposition 1: Consider first the case in which no competitor arrives and the incumbent bank has the $G$ loan. Then $L_{R}^{G}=x$. It is easy to show that the IC constraint (6) must hold tightly in equilibrium. Solving this yields:

$$
\bar{D}_{R}^{G}=[p x-\Pi] p^{-1}
$$

From the deposit pricing constraint (7), we have:

$$
\bar{D}^{G}=\frac{p \bar{D}_{R}^{G}}{1-p \gamma}
$$

Substituting $(22)$ in $(23)$ yields:

$$
\bar{D}^{G}=[p x-\Pi][1-p \gamma]^{-1}
$$

Since 99 holds, we can verify that $\bar{D}^{G} \in(0, L)$. Thus, $\bar{E}^{G}=L-\bar{D}^{G}>0$. Similarly, we can derive:

$$
\bar{D}^{g}=[q x-\Pi][1-q \gamma]^{-1}
$$

Since $p>q$, a comparison of (24) and (25) shows that

$$
\bar{D}^{G}>\bar{D}^{g}
$$

Now suppose a competitor bank arrives. Let $\widetilde{L}_{R}^{G}$ be the loan repayment set by the competitor bank. From the IC constraint (6), we have:

$$
\widetilde{D}_{R}^{G}=\left[p \widetilde{L}_{R}^{G}-\Pi\right] p^{-1}
$$

Substituting (27) in the deposit pricing constraint (7) as before gives us:

$$
\widetilde{D}^{G}=\left[p \widetilde{L}_{R}^{G}-\Pi\right][1-p \gamma]^{-1}
$$

Now recognizing that $\widetilde{E}^{G}=L-\widetilde{D}^{G}$ and using 28 , the competing bank's NPV is: 


$$
\begin{gathered}
p\left[\widetilde{L}_{R}^{G}-\widetilde{D}_{R}^{G}\right]-\widetilde{E}^{G}-\alpha-K \\
=p\left[\widetilde{L}_{R}^{G}-\widetilde{D}_{R}^{G}\right]-L+\left[p \widetilde{L}_{R}^{G}-\Pi\right][1-p \gamma]^{-1}-\alpha-K \\
=\Pi-L+\left[p \widetilde{L}_{R}^{G}-\Pi\right][1-p \gamma]^{-1}-\alpha-K
\end{gathered}
$$

The $\tilde{L}_{R}^{G}$ at which this NPV becomes zero is:

$$
\widetilde{L}_{R}^{G}=[p]^{-1}\{[1-p \gamma][L-\Pi+\alpha+K]+\Pi\}
$$

Now, given $\left[9\right.$, it follows that $\widetilde{L}_{R}^{G}=\widehat{L}_{R}^{G}<x$. From this, it follows that $\widehat{D}_{R}^{G}<\bar{D}_{R}^{G}$. Using similar analysis, it can also be shown that $\widehat{D}_{R}^{g}<\bar{D}_{R}^{g}$. The proof of $\widehat{D}_{R}^{g}<\widehat{D}_{R}^{G}$ and $\bar{D}_{R}^{g}<\bar{D}_{R}^{G}$ follows from $p>q$.

Proof Lemma 1: The regulator solves

$$
\max _{D^{G}} p\left[L_{R}^{G}-D_{R}^{G}\right]-E^{G}-\Omega\left(D^{G}\right)
$$

subject to $(5)$ - (8). Denote the regulator's choice of $D^{G}$ that maximizes (31) as $D_{O}^{G}$. Substituting for $D_{R}^{G}$ from (7) and for $E^{G}$ from (8), the first-order condition that yields $D_{O}^{G}$ is

$$
p \gamma-\Omega^{\prime}\left(D_{O}^{G}\right)=0
$$

and the convexity of $\Omega$ guarantees satisfaction of the second-order condition. Now, it follows that $D_{*}^{G}=\min \left\{\bar{D}^{G}, D_{O}^{G}\right\}$ is the optimal solution to the regulator's problem. Thus, it follows that the regulator's choice of deposit level is less than or equal to the bank's choice.

Proof of Corollary 1: Solving for the incumbent bank's expected profit at $\widetilde{L}_{R}^{G}$ (from the Proof of Proposition 1):

$$
\begin{aligned}
& =\Pi+\left[p \widetilde{L}_{R}^{G}-\Pi\right][1-p \gamma]^{-1}-L-K \\
& \left.=\alpha \quad \text { (upon substituting for } \widetilde{L}_{R}^{G} \text { from } 30\right) \\
& >0
\end{aligned}
$$

Proof of Proposition 2: To break even, the loan repayment set by a P2P lender on a $g$ loan, 
$\widetilde{L}_{R}^{g}$, must satisfy:

$$
q \widetilde{L}_{R}^{g}-L-\alpha=0
$$

which yields

$$
\widetilde{L}_{R}^{g}=[L+\alpha] q^{-1}
$$

By $(9)$, we know that $\widetilde{L}_{R}^{g}<x$.

If a P2P lender arrives, an incumbent bank will have to offer the borrower $\widetilde{L}_{R}^{g}$. From the IC constraint (6) for the incumbent bank, we have:

$$
\widehat{D}_{R}^{g}=\left[q \widetilde{L}_{R}^{g}-\Pi\right] q^{-1}
$$

and using the pricing constraint (7), we have the deposit level

$$
\widehat{D}^{g}=\left[q \widetilde{L}_{R}^{g}-\Pi\right][1-q \gamma]^{-1}
$$

Given 10 , we know (after substituting for $\widetilde{L}_{R}^{g}$ from 33 ) that $\widehat{D}_{g}<L$.

Now, at $\widetilde{L}_{R}^{g}$, the NPV of the incumbent bank is

$$
\begin{aligned}
& =q\left[\widetilde{L}_{R}^{g}-\widehat{D}_{R}^{g}\right]-\widehat{E}^{g}-K \\
& =q\left[\widetilde{L}_{R}^{g}-\widehat{D}_{R}^{g}\right]-\left[L-\widehat{D^{g}}\right]-K \\
& =\Pi+\left[q \widetilde{L}_{R}^{g}-\Pi\right][1-\gamma q]^{-1}-L-K \\
& \text { (substituting for } \widehat{D}_{R}^{g} \text { from }[34) \\
& =\Pi+[L+\alpha-\Pi][1-\gamma q]^{-1}-L-K \\
= & q \gamma[L-\Pi][1-\gamma q]^{-1}-K+\alpha[1-\gamma q]^{-1}
\end{aligned}
$$

If the NPV in (36) is non-negative, then the $\mathrm{P} 2 \mathrm{P}$ lender will be unable to pry the borrower away from the incumbent bank. From (36), we see that:

$$
q \gamma[L-\Pi][1-\gamma q]^{-1}+\alpha[1-\gamma q]^{-1}-K \geq 0
$$


if $\alpha \geq A_{2}$. In this case, no bank loses any loan to P2P lenders. In $\alpha<A_{2}$, then the bank loses $g$ loans to P2P lenders because the incumbent bank's NPV from lending is negative at the best rate the P2P platform can offer.

Using similar steps, we can show that the bank with the $G$ loan will have a non-negative NPV from lending when faced with P2P platform competition if:

$$
p \gamma[L-\Pi][1-\gamma p]^{-1}+\alpha[1-\gamma p]^{-1}-K \geq 0
$$

We can show that (38) holds if $\alpha \geq A_{1}$. This means that if $\alpha \in\left[A_{1}, A_{2}\right)$, then banks with $g$ loans lose them to P2P lenders, but banks with $G$ loans do not.

Proof of Corollary 2: Let $\mu$ be the Lebesgue measure of $\left[A_{1}, A_{2}\right)$ in Proposition 2. Then

$$
\begin{aligned}
\mu & =A_{2}-A_{1} \\
& =\gamma[p-q][L-\Pi+K]
\end{aligned}
$$

Thus,

$$
\begin{aligned}
\frac{\partial \mu}{\partial K} & =\gamma[p-q] \\
& >0
\end{aligned}
$$

To see the effect of higher capital requirements, note that we know from Lemma 1 that a bank's expected profit is strictly increasing in its leverage (deposit level), subject to the IC constraint being satisfied. Thus, if its regulatory capital requirement is raised above that needed to satisfy its IC constraint, the loan interest rate at which its profit becomes zero can become higher than the rate at which a competing bank's rate becomes zero, for some $\alpha$ realizations.

Diff-in-diff placebo test. The placebo estimation uses fictive dates for the EBA capital exercise nine and three months before, and nine and three months after the actual exercise. Using 
placebo dates before the EBA capital exercise, we analyse whether the treatment was anticipated and the parallel-trend assumption violated. This is the case when the diff-in-diff interaction term is significant. The placebo estimations after the actual treatment show that the effect on bank and $\mathrm{P} 2 \mathrm{P}$ lending is persistent but reduces with time.

We estimate the four placebo tests for equations (15), (16), and (17), which are presented in Tables 17, 18, and 19. For the estimation using placebo treatments before the actual treatment, we restrict our sample until October 2011, in order to avoid the possibility that the significance of the post-EBA period could influence the test results. The coefficient of our interest is the interaction $\mathrm{EBA}_{t}{ }^{*} \operatorname{Treated}_{b}$. The pattern of the results is the same in all three tables. The diff-in-diff interaction term is not significant in placebo tests before the EBA capital exercise. This result suggests that the treatment was not anticipated and we find no evidence that the parallel-trend assumption was violated. For placebo estimations, after the EBA capital exercise, we find that the diff-in-diff interaction term is significant. Moreover, we find that the effect of the treatment reduces over time. On the bank side, the intensity of the lending reduction due to the capital exercise diminishes with time. On the $\mathrm{P} 2 \mathrm{P}$ lending side, the extra lending on treated states also reduces.

Overall, our results are consistent with the view that the EBA stress test was not anticipated and its effect reduces over time. 
Table 17. Placebo difference-in-differences estimation bank lending by state.

This table shows that using placebo dates for the treatment, no effect on bank lending can be found, and using placebo dates after the treatment, the effect is still significant but reduces its magnitude over time. (I) presents a placebo estimation nine months before actual treatment, and (II) three months. In both estimations, the sample is restricted to the treatment date. We estimate: $\log \left(L_{t, s}\right)=\alpha_{1}$ treated $_{s} * E B A_{t}+\alpha_{2} E B A_{t}+\alpha_{3}$ treated $_{s}+\Pi W_{t, s}+u_{t, s}$. The estimation is in the state dimension. The variable $L_{t, s}$ is the total lending volume in state $s$ in month $t, E B A_{t}$ is the placebo treatment dummy, and treated $_{t, s}$ is the dummy variable that identifies banks in the treated states and is equal to one for treated states (i.e., where HELABA or NordLB were present) and zero otherwise. A treated state is one where HELABA and NordLB were present and the dependent variable is the total bank lending in that state. The control is total bank lending in other states (where HELABA or NordLB were not present). $W_{t, s}$ is a vector of control variables that includes the default probability, $\sigma$ - i.e., our proxy for risk - and interest rate is the average interest rate for new loans. ${ }^{* * *}, * *$, and $*$ represent significance at the $1 \%, 5 \%$ and $10 \%$ levels, respectively. Source: Research Data and Service Center (RDSC) of the Deutsche Bundesbank, MFI Interest Rates Statistics and Monthly Balance Sheet Statistics.

\begin{tabular}{lcccc}
\hline \hline & \multicolumn{4}{c}{ State Bank Lending } \\
\cline { 2 - 5 } & $(\mathrm{I})$ & $(\mathrm{II})$ & $(\mathrm{III})$ & $(\mathrm{IV})$ \\
& $\log \left(L_{t, s}\right)$ & $\log \left(L_{t, s}\right)$ & $\log \left(L_{t, s}\right)$ & $\log \left(L_{t, s}\right)$ \\
& $t-9$ & $t-3$ & $t+3$ & $t+9$ \\
\hline & & & & \\
EBA $_{t}{ }^{*}$ Treated $_{s}$ & -0.01 & -0.01 & $-0.05^{* * *}$ & $-0.03^{* * *}$ \\
& $(0.01)$ & $(0.01)$ & $(0.01)$ & $(0.01)$ \\
$\sigma_{t, s}$ & 0.02 & 0.02 & 0.01 & 0.01 \\
& $(0.02)$ & $(0.02)$ & $(0.02)$ & $(0.02)$ \\
Int. Rate $t, s$ & -0.02 & -0.02 & $-0.04^{*}$ & $-0.04^{*}$ \\
& $(0.02)$ & $(0.02)$ & $(0.02)$ & $(0.02)$ \\
State FE & & & & \\
Time FE & Yes & Yes & Yes & Yes \\
Cluster & Yes & Yes & Yes & Yes \\
adj. R & State & State & State & State \\
$\#$ Obs & 0.996 & 0.996 & 0.997 & 0.997 \\
\hline \hline
\end{tabular}


Table 18. Placebo difference-in-differences estimation bank lending by bank.

This table shows that using placebo dates for the treatment, no effect on bank lending can be found, and using placebo dates after the treatment, the effect is still significant but reduces its magnitude over time. (I) presents a placebo estimation nine months before actual treatment, and (II) three months. In both estimations, the sample is restricted to the treatment date. We estimate: $\log \left(L_{t, b}\right)=\alpha_{1}$ treated $_{b} * E B A_{t}+\alpha_{2} E B A_{t}+\alpha_{3}$ treated $_{b}+\Pi W_{t, b}+u_{t, b}$. The estimation is in the bank dimension. The variable $L_{t, b}$ is the total lending volume in bank $b$ in month $t, E B A_{t}$ is the placebo treatment dummy, and treated $_{t, b}$ is the dummy variable that identifies banks in the treated states and is equal to one for treated states (i.e., where HELABA or NordLB were present) and zero otherwise. A treated state is one where HELABA and NordLB were present and the dependent variable is the total bank lending in that state. The control is total bank lending in other states (where HELABA or NordLB were not present). $W_{t, b}$ is a vector of control variables that includes the default probability, $\sigma$ - i.e., our proxy for risk - and interest rate is the average interest rate for new loans. ${ }^{* * *}, * *$, and $*$ represent significance at the $1 \%, 5 \%$ and $10 \%$ levels, respectively. Source: Research Data and Service Center (RDSC) of the Deutsche Bundesbank, MFI Interest Rates Statistics and Monthly Balance Sheet Statistics.

\begin{tabular}{lcccc}
\hline \hline & \multicolumn{4}{c}{ Individual Bank Lending } \\
\cline { 2 - 5 } & $(\mathrm{I})$ & $(\mathrm{II})$ & $(\mathrm{III})$ & $(\mathrm{IV})$ \\
& $\log \left(L_{t, b}\right)$ & $\log \left(L_{t, b}\right)$ & $\log \left(L_{t, b}\right)$ & $\log \left(L_{t, b}\right)$ \\
& $t-9$ & $t-3$ & $t+3$ & $t+9$ \\
\hline EBA $_{t}{ }^{*}$ Treated $_{b}$ & 0.01 & -0.00 & $-0.05^{* *}$ & $-0.04^{*}$ \\
& $(0.01)$ & $(0.01)$ & $(0.02)$ & $(0.02)$ \\
$\sigma_{t, b}$ & -0.02 & -0.02 & $-0.02^{*}$ & $-0.02^{*}$ \\
& $(0.02)$ & $(0.02)$ & $(0.01)$ & $(0.01)$ \\
Int. Rate $t, b$ & $-0.06^{* * *}$ & $-0.06^{* * *}$ & $-0.06^{* * *}$ & $-0.06^{* * *}$ \\
& $(0.01)$ & $(0.01)$ & $(0.01)$ & $(0.01)$ \\
State FE & & & & \\
Time FE & Yes & Yes & Yes & Yes \\
Cluster & Yes & Yes & Yes & Yes \\
adj. R & Bank & Bank & Bank & Bank \\
$\#$ Obs & 0.981 & 0.981 & 0.970 & 0.970 \\
\hline \hline
\end{tabular}


Table 19. Placebo difference-in-differences estimation P2P lending.

This table shows that using placebo dates for the treatment, no effect on bank lending can be found, and using placebo dates after the treatment, the effect is still significant but reduces its magnitude over time. (I) presents a placebo estimation nine months before actual treatment, and (II) three months. In both estimations, the sample is restricted to the treatment date. We estimate: $\log \left(L_{t, s}\right)=\alpha_{1}$ treated $_{s} * E B A_{t}+\alpha_{2} E B A_{t}+\alpha_{3}$ treated $_{s}+\Pi W_{t, s}+u_{t, s}$. The estimation is in the state dimension. The variable $L_{t, s}$ is the total lending volume in state $s$ in month $t, E B A_{t}$ is the placebo treatment dummy, and treated $_{t, s}$ is the dummy variable that identifies banks in the treated states and is equal to one for treated states (i.e., where HELABA or NordLB were present) and zero otherwise. A treated state is one where HELABA and NordLB were present and the dependent variable is the total $\mathrm{P} 2 \mathrm{P}$ lending in that state. The control is total $\mathrm{P} 2 \mathrm{P}$ lending in other states (where HELABA or NordLB were not present). $W_{t, s}$ is a vector of control variables that includes the default probability, $\sigma$-i.e., our proxy for risk- and interest rate is the average interest rate for new loans. ${ }^{* *},{ }^{* *}$, and ${ }^{*}$ represent significance at the $1 \%, 5 \%$ and $10 \%$ levels, respectively. Source: Auxmoney.

\begin{tabular}{lcccc}
\hline \hline & \multicolumn{4}{c}{ P2P Lending } \\
\cline { 2 - 5 } & $(\mathrm{I})$ & $(\mathrm{II})$ & $(\mathrm{III})$ & $(\mathrm{IV})$ \\
& $\log \left(L_{t, s}\right)$ & $\log \left(L_{t, s}\right)$ & $\log \left(L_{t, s}\right)$ & $\log \left(L_{t, s}\right)$ \\
& $t-9$ & $t-3$ & $t+3$ & $t+9$ \\
\hline & & & & \\
EBA $_{t}{ }^{*}$ Treated $_{s}$ & 0.04 & 0.19 & $0.20^{* * *}$ & $0.17^{* * *}$ \\
& $(0.09)$ & $(0.16)$ & $(0.06)$ & $(0.06)$ \\
$\sigma_{t, s}$ & -0.02 & -0.02 & $-0.02^{* *}$ & $-0.02^{* *}$ \\
& $(0.01)$ & $(0.01)$ & $(0.00)$ & $(0.00)$ \\
Int. Rate $t, s$ & $0.18^{* * *}$ & $0.18^{* * *}$ & 0.03 & 0.03 \\
& $(0.05)$ & $(0.05)$ & $(0.02)$ & $(0.02)$ \\
State FE & & & & \\
Time FE & Yes & Yes & Yes & Yes \\
Cluster & Yes & Yes & Yes & Yes \\
adj. R & State & State & State & State \\
\# Obs & 0.531 & 0.532 & 0.790 & 0.790 \\
\hline \hline
\end{tabular}




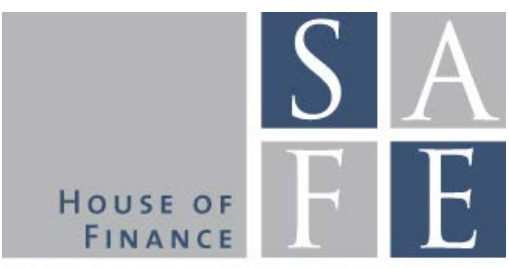

WORKING PAPER SERIES

\section{Recent Issues}

No. 205 Horst Entorf, Jia Hou

No. 204 Loriana Pelizzon, Matteo

Sottocornola

No. 203 Florian Hett, Felix Schmidt

No. 202 Tobias H. Tröger

No. 201 Dirk Krueger, Alexander Ludwig

No. 200 Nils Grevenbrock, Max Groneck, Alexander Ludwig, Alexander Zimper

No. 199 Tobias H. Tröger

No. 198 Henning Hesse, Boris Hofmann, James Weber

No. 197 Benjamin Clapham, Peter Gomber, Martin Haferkorn, Paul Jentsch, Sven Panz

No. 196 Benjamin Clapham, Peter Gomber, Sven Panz

No. 195 Benjamin Clapham, Peter Gomber, Martin Haferkorn, Sven Panz

No. 194 Baptiste Massenot

No. 193 Mario Bellia, Roberto Panzica, Loriana Pelizzon, Tuomas Peltonen
Financial Education for the Disadvantaged? A Review

The Impact of Monetary Policy Interventions on the Insurance Industry

Pushing Through or Slacking Off? Heterogeneity in the Reaction to Rank Feedback

Germany's Reluctance to Regulate Related Party Transactions

Optimal Taxes in the OLG Model with Uninsurable Idiosyncratic Income Risk

Cognition, Optimism and the Formation of Age-Dependent Survival Beliefs

Regulation of Crowdfunding in Germany

The Macroeconomic Effect of Asset Purchases Revisited

Circuit Breakers - A Survey among International Trading Venues

Coordination of Circuit Breakers? Volume Migration and Volatility Spillover in Fragmented Markets

Managing Excess Volatility: Design and Effectiveness of Circuit Breakers

A Business Cycle Model with Neuroeconomic Foundations

The Demand for Central Clearing: To Clear or Not to Clear, That is the Question 